\title{
The Question of 2047: Constitutional Fate of "One Country, Two Systems" in Hong Kong
}

\author{
Tu Yunxin* ${ }^{*}$
}

(Received 04 November 2019; accepted 05 December 2019)

\begin{abstract}
The history of Hong Kong is intertwined with British colonialism and China's Hong Kong policies. This history offers unique and important lessons on the rise and fall of Hong Kong's constitutional order. In accordance with the 1984 Sino-British Joint Declaration, China declares 12 basic policies regarding Hong Kong and has translated these into the 1990 Hong Kong Basic Law. It is generally held that "One Country, Two Systems" will be the main constitutional architecture of Hong Kong for 50 years, and it will remain basically unchanged even after 2047. However, there are obvious difficulties and enormous differences on the interpretation of Article 5 of the Hong Kong Basic Law concerning the true meaning of "unchanged for 50 years." Recent years have witnessed the great need for deciphering the time-code of the Basic Law because the question of 2047 draws closer and closer to the central stage for the determination of Hong Kong's constitutional future. This Article aims to provide legal analysis on Article 5 of Hong Kong Basic Law and the constitutional fate of Hong Kong toward 2047. It distinguishes all sorts of Article 5 interpretations into three broad categories: "Unchanged for 50 years" as international promise, "unchanged for 50 years" as political commitment, and "unchanged for 50 years" as constitutional obligation. Different approaches have been utilized for various constitutional interpretations. But all in all, the constitutional puzzles regarding "unchanged for 50 years" must be addressed within the framework of the temporality of the Basic Law in a fast-paced world. In order to maintain the constitutional stability and endurance, to secure the unamendability of "One Country, Two Systems" in 2047 will be the best blessing for Hong Kong in every possible way.
\end{abstract}

Keywords: Hong Kong Basic Law; Sino-British Joint Declaration; the question of 2047; temporality; unchanged for 50 years; international promise; constitutional obligation; political commitment; One Country; Two Systems; Occupying Central Movement; extradition bill crisis; Hong Kong National Security Law; originalism; living constitutionalism; constitutional unamendability

The Master said, "At fifteen my mind was set on learning. At thirty my character had been formed. At forty I had no more perplexities. At fifty I knew the Mandate of Heaven

\footnotetext{
${ }^{*}$ Tu Yunxin (LL.B, LL.M, and Ph.D in Law), Assistant Professor of Law at Fudan University Law School, Research Fellow at Fudan University Center for Human Rights Studies, Shanghai, China. Email address: tuyunxin@fudan.edu.cn or chinatu@live. com. I am greatly indebted to the research fund provided by Fudan University. I must thank Professor Laurence H. Tribe, Professor Albert H. Y. Chen, Professor Fan Zhou, Jimmy Ma (SBS, JP), Professor Lui Tai-lok (JP), Professor David M. O’Brien, Professor Karen J. Alter, Ms. Xiao Xu, Ms. Yaxiu Zhu and Mr. Yingli Zeng for their inspirations and great help. I sincerely extend my gratitude to editors Jule Mulder, Jac Andrade, Evan Sweeney, Kristina Hopf, David Crosse, Nick Gallagher, Andrew Dagen, and Alexandra Castro for their excellent editorial comments and suggestions. I also thank the students who participated in my constitutional law classes in 2018 and 2019. All errors and omissions remain mine alone. An earlier version of the manuscript was done in December 2018 and the draft was finalized in September 2020.
} 
(T'ien-ming). At sixty I was at ease with whatever I heard. At seventy I could follow my heart's desire without transgressing moral principles."

- Confucius (551-479 BC)

The past carries with it a temporal index by which it is referred to redemption. There is a secret agreement between past generations and the present one. Our coming was expected on earth. Like every generation that preceded us, we have been endowed with a weak Messianic power, a power to which the past has a claim. That claim cannot be settled cheaply. Historical materialists are aware of that. ${ }^{2}$

- Walter Benjamin (1892-1940)

\section{A. Introduction}

Stepping into the third decade after the resumption of sovereignty over Hong Kong by the People's Republic of China ("PRC"), the life of the Hong Kong Basic $\mathrm{Law}^{3}$ in a changing time seems to remind us of the opening of Dickens's Tale of Two Cities: "[T] he spring of hope and the winter of

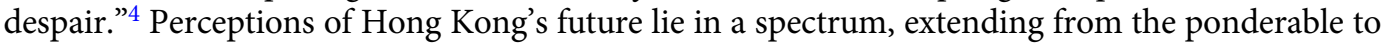
the imponderable. ${ }^{5}$ Like any other changing society, one thing is certain-laws in Hong Kong do not exist in a vacuum. Unexpected circumstances that arise in the operation of the Hong Kong Basic Law may fortuitously result in drastic changes for the city and its people. After more than two decades of China's implementation of "One Country, Two Systems" ("OCTS"), ${ }^{6}$ the question of 2047 draws closer and closer to the central stage for the determination of Hong Kong's constitutional future. When one embarks upon a journey with more meaning and conviction, ${ }^{7}$ it is generally held that OCTS will be the main constitutional architecture of Hong Kong for 50 years and it will remain basically unchanged even after 2047. However, there are obvious difficulties and enormous differences on the interpretation of Article 5 of the Hong Kong Basic Law, which provides a phrase called "unchanged for 50 years." ${ }^{8}$ Some scholars have argued for the continuation of OCTS without any explicit time limit, ${ }^{9}$ and some have suggested that OCTS shall be deemed as a transitory arrangement with an expiration date of June $30,2047 .{ }^{10}$ There are also scholars who contend that " $[\mathrm{i}] \mathrm{t}$ is unclear whether the ultimate goal is to retain two equally thriving but different systems, or whether it is to assimilate Hong Kong into the mainland politically, legally, culturally,

\footnotetext{
${ }^{1}$ Wing-Tsit Chan, A Source Book in Chinese Philosophy 22 (1963).

${ }^{2}$ Walter Benjamin, Theses on the Philosophy of History, in ILLuminations 254 (Hannah Arendt ed., Harry Zohn trans. 1968).

${ }^{3}$ XiangGang Jiben Fa (H.K.) [hereinafter Basic Law].

${ }^{4}$ See generally Charles Dickens, A TAle of Two Cities bk. I, ch. 1.

${ }^{5}$ Anthony Neoh, Hong Kong's Future: The View of a Hong Kong Lawyer, 22 CAL. W. InT'L L.J. 309, 352 (1992).

${ }^{6}$ Basic Law at pmbl., art. 5.

${ }^{7}$ Neoh, supra note 5.

${ }^{8}$ See Yash Ghai, Hong Kong's New Constitutional Order: The Resumption of Chinese Sovereignty and the Basic Law ch. 5 (2010); Danny Gittings, Introduction to the Hong Kong Basic Law 219-22 (2d ed. 2016); I. Grenville Cross, Book Review: Introduction to the Hong Kong Basic Law, 44 H.K. L.J. 961 (2014) (reviewing DANNY Gittings, Introduction to the Hong Kong Basic Law (1st ed. 2013)); Sienho Yee, Introduction to the Hong Kong Basic Law, 13 Chinese J. Int'L L. 233 (2014) (reviewing Danny Gittings, Introduction to the Hong Kong Basic LAW (1st ed. 2013)).

${ }^{9}$ Wang Shuwen, Introduction to the Basic Law of Hong Kong Special Administrative Region 102 (2d ed. 2009); Danny Gittings, Changing Expectations: How the Rule of Law Fared in the First Decade of the Hong Kong SAR, 2007 H.K. J. 1, 3-4; Danny Gittings, What Will Happen to Hong Kong After 2047, 42 CAL. W. InT'L L.J. 37 (2011); Benny Y.T. Tai, Basic Law, Basic Politics: The Constitutional Game of Hong Kong, 37 H.K. L.J. 503, 577 (2007); GITTINGS, supra note 8, at 314-15.

${ }^{10}$ Kenneth Ka-Lok Chan, Taking Stock of “One Country, Two Systems," in "One CounTry, Two Systems" In CRISIS 35, 54 (Yiu-chung Wong ed. 2004); Robert J. Morris, The "Replacement" Chief Executive's Two-Year Term: A Pure and Unambiguous Common Law Analysis, 35 H.K. L.J. 17, 22, 24 (2005).
} 
and ideologically." 11 Referring to both the Chinese and English text of Article 5 of Hong Kong Basic Law, it is shown that the phrase "unchanged for 50 years" is separated from the statement that "the previous capitalist system and way of life shall remain unchanged" by a comma, making it unclear what the reference to fifty years precisely means. ${ }^{12}$ Thus, the linguistic ambiguity has created broad space and various possibilities for those competing political and legal interpretations on the constitutional provision.

This Article purports to distinguish all sorts of Article 5 interpretations that relate to Hong Kong's constitutional future into three broad categories: "Unchanged for 50 years" as international promise, "unchanged for 50 years" as political commitment, and "unchanged for 50 years" as constitutional obligation. There has been a large volume of literature spawned upon OCTS. The constitutional future of Hong Kong was intensively analyzed and debated during the 1980s and 1990s, but only sporadic and incomprehensive legal analysis for the question of 2047 can be found at this time. In this Article, I begin with an exploration of the historical background of the Hong Kong issue that extends across nearly 180 years. The historic journey is a series of lessons which guide us to understand the sociopolitical context of the Hong Kong issue and the ways China has responded. In doing so, this Article aims to provide the political-legal structure of the original design of OCTS as well as the legislative intent of the Basic Law. Next, in Section C, this Article surveys the slightly more than two decades of China's implementation of OCTS that is central to the life of the Basic Law. This observation is also essential because this period of time, short as it might be, is our own best of times or worst of times that connects the pre-1997 colonial past and the post-2047 uncertain future. This part provides four phases of the Basic Law implementation which gradually shaped our contemporary understanding of OCTS. To predict Hong Kong's constitutional fate, one inevitably needs to look at the past of its real constitutional life. Section $\mathrm{D}$ attempts to provide a constitutionally desirable interpretation of the true meaning of "unchanged for 50 years" as enshrined in Article 5 of the Basic Law. Theorizing the constitutional paradigms of Article 5 interpretation sparks insights by rethinking the Hong Kong issue in the context of China's centennial project-the national unification of China. It is indicated that to conceptualize the question of 2047 from a constitutional perspective is desirable not only for China itself but also for the world as it is such a fundamental issue that affects all humanity. This Article argues that Article 5 of the Hong Kong Basic Law must be thoroughly examined in the context of its political and legal history. There was a silent de facto constitutional revolution for Hong Kong in 1997 that was the result of the 1984 Sino-British Joint Declaration, but the Hong Kong issue was an "unfinished project" at that point because the incarnation of OCTS had not been given concrete forms. The Sino-British deal shall not be construed as a ceiling but as a floor for any further constitutional evolution for the people of Hong Kong and for China as its sovereign. This part shows that there are three general dimensions of Article 5 of the Basic Law, all of which must be carefully and systematically analyzed in order to clarify the true meaning of "unchanged for 50 years." Because OCTS has never been construed by the founders as a "once and for all" solution for Hong Kong, all competing interpretations, including originalism and living constitutionalism, are subject to open discussions and must be tested with all changing societal circumstances. Constitutional fluidity and continuity both serve as compelling reasons for OCTS to be continued after 2047. Section E tentatively concludes this Article by arguing that the question of 2047 shall be addressed via careful analysis of temporality of Basic Law in the context of China's grand project of national unification as a sovereign and prosperous nation if the two systems are given chances for coexistence and co-progressiveness.

\footnotetext{
${ }^{11}$ Johannes Chan, Civil Liberties, Rule of Law and Human Rights: The Hong Kong Special Administrative Region in its First Four Years, in The First Tung Chee-Hwa Administration: The First Five Years of the Hong Kong Special Administrative Region 89, 116 (Lau Siu-kai ed., 2002).

${ }^{12}$ GitTings, supra note 8 , at 37 .
} 


\section{B. The Historical Background of Hong Kong Basic Law}

The history of homo sapiens in Hong Kong can be traced back to the Neolithic Age and even much earlier archaeologically. The land mass had been under ancient Chinese rule since the Qin dynasty (221-207 BCE) when Qin Shi Huang, the first emperor of a unified China and the founder of the Qin dynasty, initially set up governmental institutions there. Nevertheless, many historians treated 1841, the year when the British vessels landed on the island, as the starting point of the modern history of Hong Kong. ${ }^{13}$ The advent of British colonialism opens a new chapter for Hong Kong's journey that extends nearly 180 years. ${ }^{14}$

The signing of the Treaty of Nanking ${ }^{15}$ on August 29, 1842 between Imperial China and Great Britain marks a new era of Chinese tariff history. ${ }^{16}$ But the historical event is much more significant than its trade impacts. Much of the Chinese historical narrative for its long road of modernization actually began when the first Opium War ended in 1842. One of the everlasting memories for the Chinese people is what is provided by Article 3 of the treaty in which the Qing government agreed to cede Hong Kong Island to Great Britain "in perpetuity" for trade purposes. ${ }^{17}$ With growing western imperialism in the $1850 \mathrm{~s},{ }^{18}$ trade disputes between Imperial China and the UK led to the Second Opium War, which lasted from 1856 to 1860 . The year 1860 witnessed the burning of the Summer Palaces in Peking, which was a heavy blow and a great humiliation for the Chinese people. Shortly after that, a series of what the Chinese truly believed were "unequal treaties" were concluded, of which the most notable is the Convention of Peking. ${ }^{19}$ In accordance with Article 6 of the Convention, the Kowloon Peninsula and Stonecutters Island (Ngong Shuen Chau) in Hong Kong were ceded to Britain in perpetuity. ${ }^{20}$ When Imperial China was at its weakest in 1898 , more treaty ports were set to open for trade, and land leases and concessions were most common in coastal Chinese cities, notably Shanghai and Canton. Following the Sino-Japanese War in 1894, Britain took advantage of the other imperialist powers' scramble to carve up China and forced the Qing government in 1898 to sign the Convention for the Extension of Hong Kong Territory ${ }^{21}$ which compelled China to lease to Britain the "New Territories" for 99 years rent-free, expiring on June 30, 1997.22

The Hong Kong Letters Patent and the Hong Kong Royal Instructions, though "crude and rudimentary," were among the very first batch of constitutional documents ${ }^{23}$ that were issued by Queen Victoria to establish British rule in Hong Kong. ${ }^{24}$ For more than 150 years, Hong

\footnotetext{
${ }^{13}$ G. B. Endacott, A History of Hong Kong 4 (2d ed. 1977).

${ }^{14}$ See generally Richard Cullen, Hong Kong Constitutionalism: The British Legacy and the Chinese Future (2020).

${ }^{15}$ Treaty of Peace, Friendship, and Commerce Between Her Majesty the Queen of Great Britain and Ireland and the Emperor of China, Aug. 29, 1984, 93 Consol. T. S. 465 [hereinafter Treaty of Nanking]. The Treaty of Nanking was signed in Nanking on August 29, 1842 and ratifications were exchanged in Hong Kong on June 26, 1843.

${ }^{16}$ Ching-lin Hsia, Treaty Relations Between China and Great Britain, 8 ChInESE Soc. \& Pol. SCI. Rev. 116, 118 (1924).

${ }^{17}$ Treaty of Nanking at art. 3.

${ }^{18}$ See Robert Nield, Treaty Ports and Other Foreign Stations in China, 50 J. RoYAl AsIATIC Soc. H.K. BranCH 123, 126-27 (2010).

${ }^{19}$ Convention of Peking Between China and the United Kingdom, Oct. 24, 1860, 123 Consol. T.S. 71 [hereinafter Convention of Peking].

${ }^{20}$ Convention of Peking at art. 6. See also Nield, supra note 18 , at 123, 131.

${ }^{21}$ Convention Between the United Kingdom and China Respecting an Extension of Hong Kong Territory, June 9, 1898, 186 Consol. T.S. 310 [hereinafter Second Convention of Peking].

${ }^{22}$ China Foreign Policy and Government Guide: Strategic Information and Developments vol. 123 (2011).

${ }^{23}$ Albert H. Y. Chen, The Interpretation of the Basic Law-Common Law and Mainland Chinese Perspectives, 30 H.K. L.J. 380 (2000).

${ }^{24}$ The Letters Patent (or The Hong Kong Charter) of April 5, 1843 defined the constitutional structure of Hong Kong as a Crown Colony. Subsequently, major amendments of the Letters Patent took place in 1875, 1877, 1888, and 1917. The Royal Instructions of April 6, 1843 provided instructions for setting up the Executive Council and the Legislative Council as well as regulating their work. A major amendment for Royal Instructions occurred in 1917. See LEGISLATIVE COUNCIL LIBRARY, LEGCO INFOPACK No. LC04/2011-12, LETTERS PATENT (2011), https://www.legco.gov.hk/general/english/library/
} 
Kong was a colony governed by twenty-eight proconsuls and commanders-in-chief appointed by the British government. The established and expanded colonial history over Hong Kong was also accompanied by rising nationalist revolts and revolutions across China. After the Republic of China ("ROC") overthrew the Manchurian Qing government in 1911, it promulgated the Provisional Constitution of the ROC in 1912. Though the Provisional Constitution did not directly mention the Hong Kong issue, Sun Yat-sen (1866-1925), the founding father of the first Asian republic, thought those unequal treaties, including the Treaty of Nanking and the like, should be abolished. For the sake of the newly born republic and badly needed international recognition, Sun Yat-sen and his republic government did not nullify those unequal treaties and continued to recognize and further maintain the status quo of Hong Kong. ${ }^{25}$ During World War II, Hong Kong was under Japanese rule from 1941 to $1945 .{ }^{26}$ When the war was at its peak in 1943, the UK and the US willingly renounced their extraterritorial rights and returned the concession areas in Shanghai, Canton, Tianjin, Hankou, and other treaty ports to China, which unfortunately did not include Hong Kong. In 1942, the Colonial Office, traditionally a strong proponent of Hong Kong's retention, suggested that the city might be returned to China after victory in the war, assuming satisfactory international cooperation. ${ }^{27}$ Later, well-known documents such as the 1943 Cairo Declaration and the 1945 Potsdam Proclamation requested the stolen Chinese territories such as Manchuria, Formosa (Taiwan), and the Pescadores (Penghu) to be returned to China $^{28}$ without the Hong Kong issue clearly mentioned. British control over Hong Kong was restored on August 30, 1945 after the Japanese surrendered to the victorious Allied Powers. Almost at the same time, the reversion of Hong Kong to China, for which the Chinese Nationalist government had maneuvered, was thwarted finally by Winston Churchill. ${ }^{29}$

\section{People's Republic of China's Hong Kong Policies During Early Years}

Amid the painful experience of subordination and political turmoil for the first half of the twentieth century, with what it called "glorious revolutionary tradition and relentless struggles," the Communist Party of China ("CPC") emerged as a leading opponent to the republic government, which was run by the Chinese Nationalist Party, known as Kuomintang, ("KMT"). China's War of Liberation was fought between the two adversaries from 1945 to 1949 . This is actually the third and last revolutionary civil war between the two major political parties prior to the founding of the PRC. During the civil war, Hong Kong, as a British overseas territory, was outside the ambit of the cannons.

As is familiar to all, the PRC was established in Beijing on October 1, 1949 by Mao Zedong (1893-1976). This historical event was a clear message that the CPC had victory over the civil war. But for the first few months of the PRC, some territories, like Tibet, had not been under firmly effective control until the end of 1951. On October 14, 1949, the city of Guangzhou was set free by the People's Liberation Army ("PLA") and the PLA continued to march to the north of the Shenzhen River. Hong Kong was just within a foot of PLA's Fourth Field Army on October 17, 1949. The increased number of British troops in Hong Kong from roughly 5,000 to about

infopacks/yr11-12/1112infopacks-lc-04-e.pdf; LeGISLATIVE COUNCIL LIBRARY, LEGCo INFOPACK NO. LC03/2011-12, LETTERS PATENT (2011), https://www.legco.gov.hk/general/english/library/infopacks/yr11-12/1112infopacks-lc-03-e.pdf.

${ }^{25}$ Gao Fang, The Origin and Development of Unequal Treaties in Contemporary China, Social Sciences in NANJING，NO. 2 18-28 (1999). [高放: 近现代中国不平等条约的来龙去脉, 《南京社会科学》1999年第2期, 第18-28 页]. All English translations done by the author of this article.

${ }^{26}$ Chi-Kwan Mark, Hong Kong and the Cold War: Anglo-American Relations 1949-1957 14 (2004).

${ }^{27}$ Peter Wesley-Smith, The Future of Hong Kong: Not What It Used to Be, 30 VAND. J. Transnat'L L. 421 (1997).

${ }^{28}$ Chun-i Chen et al., Contemporary Practice and Judicial Decisions of the Republic of China (Taiwan) Relating to International Law, 32 Chinese (TAIWAN) Y.B. InT'L L. \& AfF. 221, 282 (2014); Jianming Shen, Sovereignty, Statehood, Self-Determination, and the Issue of Taiwan, 15 AM. U. INT'L L. REV. 1101, 1115 (2000).

${ }^{29}$ Brian Hook, Political Change in Hong Kong, 136 CHINA Q. 840, 841 (1993). 
30,000 suggested a potential international armed conflict. Winston Churchill, consistent with his position in 1945, expressed adamant opposition to the rendition of Hong Kong, ${ }^{30}$ and it seemed that the British government was obviously prepared for any further armed conflicts over the city "under the British flag." ${ }^{31}$ Later, British archives and memoranda show that in 1948 and 1949 the British government at least studied and prepared both long-term and short-term policies for Hong Kong as it kept close eyes on the changing circumstances across the Shenzhen River. ${ }^{32}$

Despite the fact that there was a concentration of Chinese troops near the Shenzhen River in October 1949, the communist government did not attempt to take over the colony by force. ${ }^{33}$ Furthermore, from February 1950 on, no formal demand for the return of Hong Kong was made by the PRC until 1982. ${ }^{34}$ There is much confusion on, as well as explanation for, why the Chinese troops did not march across the Shenzhen River in October 1949. Suppose that Hong Kong was to be returned to China. The newly established Chinese government would have several possible options; military force was just the most visible one. The Chinese government could very well have cut off all the water and food supplies upon which Hong Kong had high degrees of dependence. To the surprise of most people, the Chinese army stopped at the border and the newly established Chinese government even guaranteed the water supply to Hong Kong. There are a number of reasons for this and the most important ones should come from the Chinese side.

First, the Hong Kong issue was not initially on the top of the priority list for the CPC. The CPC actually had a grander vision of national unification when it felt great confidence after its victory in the civil war during the second half of the 1940s. According to Mao Zedong's strategy, the fact that the return of Hong Kong was not raised did not mean Hong Kong would never be returned. In December 1946, Mao said to western reporters, when the Hong Kong question was presented, "China is huge, many places are not well governed, why should we focus on such a small place firstly? It can be solved via negotiations in the future." 35 On January 19, 1949, the Instructions of the Chinese Communist Party Central Committee on Foreign Affairs was released. It was a document drafted by Zhou En'lai and revised by Mao Zedong. It reads as follows:

In principle, all the privileges enjoyed by the imperialists in China must be renounced, the Chinese people must achieve full dependence and liberation, this position is firm and unshakable. However, on the measures and steps of how we achieve [those goals], it should be dealt differently in accordance with the nature and circumstances of the issues. Any issues, which are beneficiary for the Chinese people and are possible to solve, must be raised and resolved; some of them which are not possible to solve, shall be postponed to resolve. Any issues which do not have harms or without great harms, even if, they are easy to solve, need not be resolved in a hurry. Any issues, which are not clearly researched or are not ripe to solve, should never to be resolved at once. ${ }^{36}$

From this document, it can be deduced that the issue of Hong Kong belonged in the category of issues which needed not be resolved in a hurry. And this judgment was further supported by later historical facts. In early 1949, when meeting with Soviet Union representative Anastas Ivanovich Mikoyan (1895-1978), Mao said to him:

[U]nder such circumstance [of the civil war], it is of no great meaningfulness to solve the issues of Hong Kong and Macau. To the contrary, I am afraid it is more useful for us to make use of those

\footnotetext{
${ }^{30}$ Wesley-Smith, supra note 27 , at 426.

${ }^{31} I$ d.

${ }^{32} I d$. at $432-34$.

${ }^{33} I d$. at 436.

${ }^{34} I d$.

${ }^{35} 4$ MAO ZEDONG, COLleCtion OF WORK OF MAO ZEDONG 207 (1996). [毛泽东：《毛泽东文集》第 4卷, 北京：人民 出版社凶1996年, 第 207页。].

${ }^{36}$ See 26 Selected PAPERS Since the Founding Of THE ChInESE COMMUnist PARTY (1921-1949) 55 (2011). [《建党以来 重要文献选编》 (一九ニー- 一九四九) ( 第26册), 北京：中央文献出版社, 2011年, 第55页。].
} 
two places, especially Hong Kong, to develop our international relations and to facilitate import and export trades. All in all, it must be up to the final decision corresponding to the changing circumstances. ${ }^{37}$

Second, there was full consideration for the PRC's international relations at that time. It was fairly easy to imagine that the communist government would be isolated in the international community once it was declared independent. Hong Kong could serve as a "window" amid the western blockade; not liberating Hong Kong would prevent a British-American fortress against China in the city. After serious and secret communications with the British, ${ }^{38}$ on January 5, 1950, the Clement Attlee government recognized the Communist regime as the de facto government of China, making the UK among the first western powers to afford such recognition to the PRC. This recognition was also reflected in the decision of Civil Air Transport Inc. v. Chennault and Others (1950) by the Supreme Court of Hong Kong, which is not actually the court of last resort under British rule. ${ }^{39}$

Third, there were very pragmatic economic considerations for the PRC to utilize Hong Kong for trade purposes. Mao told to Anastas Ivanovich Mikoyan that maintaining the status quo of Hong Kong could facilitate import and export trades for China. This stance was reinforced when Premier Zhou En'lai was in charge of China's foreign affairs. Later facts show that Hong Kong remains as China's only open door to the rest of the world. It helped, if not kept China alive during the severe trade embargoes when the Korean War broke out. ${ }^{40}$

In 1956, massive pro-nationalist riots erupted in Hong Kong, causing Governor Alexander Grantham (1899-1978) to introduce an emergency law at the time. ${ }^{41}$ Chinese premier Zhou En'lai called the colonial government to quell the riots allegedly led by the Chinese Nationalist Party in Taiwan. In the following year, Zhou delivered remarks at the Symposium of the Business People in Shanghai and openly expressed the Central People's Government's positions regarding the Hong Kong issue. The core can be summarized by the following points: (1) Hong Kong will one day be reverted to China; (2) Policies on Hong Kong shall be differentiated from that of the mainland, capitalistic systems shall be run under British rule, and socialism does not apply to Hong Kong; (3) Hong Kong should remain a free international port and should be useful and beneficial for the economic development of socialist China; (4) Hong Kong can serve as the base for our foreign economic ties and can be utilized for foreign investment and foreign currency; and (5) We shall cooperate with Hong Kong business people and the future collaboration is promising. ${ }^{42}$ Zhou En'lai's remarks clearly represented Beijing's Hong Kong policy. The Chinese foreign ministry termed it later as "long-term planning, full utilization." ${ }^{3}$

In the 1960s, under governor Sir David Trench (1915-1988), anti-colonial leftist riots spread in the summer of 1967, which were widely deemed to be one of the most important historic episodes of the colonial history in Hong Kong's post-war era. ${ }^{44}$ Triggered by an industrial dispute in an

\footnotetext{
${ }^{37}$ Party Literature Research Center of the CPC Central Committee, Biography of Mao Zedong (1893-1949) 948 (2004). [中共中央文献研究室：《毛泽东传 ( 1893-1949)》, 北京 : 中央文献出版社, 2004年, 第 948 页。].

${ }^{38}$ The Central People's Government secretly sent the then-Hong Kong governor Sir Alexander Grantham (1899-1978) a letter outlining "three prerequisites" for maintaining the status quo of Hong Kong: (1) Hong Kong should not be used as a military base against the PRC; (2) there shall not be activities aimed at destroying the popular trust of the PRC; and (3) PRC Personals in Hong Kong must be secured.

${ }^{39}$ L. C. Green, The Recognition of Communist China, 3 INT'L L. Q. 418 (1950).

${ }^{40}$ Wesley-Smith, supra note 27, at 437.

${ }^{41}$ Max W. L. Wong, Social Control and Political Order-Decolonisation and the Use of Emergency Regulations in Hong Kong, 41 H.K. L.J. 133, 149 (2011).

${ }^{42}$ See Zhou En'lai, Premier, People's Republic of China, Remarks at Symposium of the Business People in Shanghai: On the Issue of Hong Kong (April 28, 1957). [周恩来：《周恩来统一战线文选》,北京：人民出版社, 1984年, 第 353-354页。].

${ }^{43}$ Michael C. Davis, International Commitments to Keep: Hong Kong Beyond 1997, 22 S. ILL. UNIV. L.J. 293, 303 (1998); Ray Yep, The 1967 Riots in Hong Kong: The Diplomatic and Domestic Fronts of the Colonial Governor, 193 CHINA Q. 122,125 (2008).

${ }^{44}$ Yep, supra note 43, at 122.
} 
artificial flower factory in Kowloon, the 1967 riots posed a grave crisis for the British colonial governance. ${ }^{45}$ Many treated the event as the watershed for the post-war colonial rule, stirring up some of the fundamental changes in socioeconomic policies. ${ }^{46}$ Given that the nationwide grassroot Chinese Cultural Revolution was climbing to its zenith, the 1967 event is also believed to be a "spillover" of China's leftist movement. ${ }^{47}$ Later released records of the National Archives in London proved that the United Kingdom was quite uncertain over the future political development in China and was confused over the communist leaders' revolutionary tactics. ${ }^{48}$ Though the banners of the Red Guards were held highly and the slogan "We Will Liberate Hong Kong" were screamed loudly, the Chinese military remained calm and constrained; thus, the "long-term planning, full utilization" policy toward Hong Kong sustained and was kept on its way until the end of 1970 s.

\section{1984 Sino-British Joint Declaration ${ }^{49}$}

As history turned to the 1970s, China's Hong Kong policy of "long-term planning, full utilization" survived even the catastrophic Cultural Revolution, which brought many uncertainties. In a time when the world was still experiencing the Cold War, geopolitics shifted slowly and unexpectedly. In July 1971, after China had troubles with the Soviet Union, Henry Kissinger paid a secret visit to China, and in the following year, China and the United States signed the Shanghai Communique during Nixon's China visit. ${ }^{50}$ In October 1971, the United Nations General Assembly adopted Resolution 2758, which restored the legitimate seat of the PRC. ${ }^{51}$ During this vital vote at the $\mathrm{UN}$, the U.K. voted for the resolution, which was of great help to China's struggles for international recognition. After twenty-two years of diplomatic relations at the chargé d'affaires level between the PRC and the U.K., the two sides exchanged ambassadors on March 13, 1972. As a former British colony, Hong Kong was on the United Nations List of Non-Self-Governing Territories in $1946,{ }^{52}$ but in 1972 , China formally requested that the United Nations remove Hong Kong and Macau from that list. ${ }^{53}$ Four years later, Mao Zedong and Zhou En'lai passed away, and the Chinese Cultural Revolution officially ended in October 1976.

Both 1978 and 1979 are significant for contemporary China in terms of their impacts on the future direction of the country. After the Third Plenum of the 11th Central Committee Congress of the Communist Party of China in December 1978, Deng Xiaoping emerged as chief architect of China's opening-up and reform. On New Year's Day of 1979, China's highest legislature, the Standing Committee of National People's Congress ("NPCSC") issued a historical document - "Message to Compatriots in Taiwan"-calling for peaceful unification. On the same day, the Chinese government simultaneously ordered the PLA to stop the bombardment of Jinmen (Quemoy) Island on which the war had lasted for twenty-one years. 1979 marked a giant shift of China's Taiwan policy and laid out a grand outline for one of China's biggest centenary projects-complete national unification. A synoptic view of the 1979 "Message to Compatriots in Taiwan" shows some of the key points of China's Taiwan policy: (1) There is only one China

\footnotetext{
${ }^{45} I d$. at 123.

${ }^{46} I d$.

${ }^{47}$ H. L. Fu \& Richard Cullen, Political Policing in Hong Kong, 33 H.K. L.J. 199, 207 (2003).

${ }^{48}$ Yep, supra note 43 , at 138.

${ }^{49}$ Joint Declaration of the Government of the United Kingdom of Great Britain and Northern Ireland and the Government of the People's Republic of China on the Question of Hong Kong, Dec. 19, 1984, 1399 U.N.T.S. 33 [hereinafter Sino-British Joint Declaration].

${ }^{50}$ Ma Zhengang, China-U.S. Relations: A Sober-Minded Assessment with High Expectations, 18 CHINA INT'L STUD. 57, 58 (2009).

${ }^{51}$ G.A. Res. 2758 (XXVI) (Oct. 25, 1971) (seventy-six voted for, thirty-five voted against and seventeen abstained).

${ }^{52}$ G.A. Res. 66 (I) (Dec. 14, 1946).

${ }^{53}$ Stuart Hargreaves, From the "Fragrant Harbour" to "Occupy Central": Rule of Law Discourse \& Hong Kong's Democratic Development, 9 J. PARLiamentary \& Pol. L. 519, 527-28 (2015).
} 
in the world; (2) Taiwan shall never get independence; (3) respect the status quo on Taiwan and the opinions of Taiwanese people; (4) end military confrontation across the strait; and (5) realize the three linkages of postal, commercial, and transportation services. ${ }^{54}$ On the eve of the Chinese National Day in 1981, the Chairman of the Standing Committee of the National People's Congress, Mr. Ye Jian Ying, made a statement that "after peaceful reunification, Taiwan may become a special administrative region with a high degree of autonomy which means that the existing social system, economic system and life-style of Taiwan will remain unchanged, and so will Taiwan's economic and cultural relationship with foreign countries." $55 \mathrm{Mr}$. Ye Jian Ying's statement further clarified the core content of the 1979 "Message to Compatriots in Taiwan," that is OCTS, a phrase which Deng Xiaoping succinctly summarized several months later. Another thing worthy of mentioning is that the concept of OCTS was actually not attractive to Taiwan. ${ }^{56}$ Taiwanese leader Chiang Ching-kuo (1910-1988) later proposed "One China, Better System" 57 as a countermeasure policy against Beijing.

It is fairly clear that OCTS is a unique Chinese invention that aimed to tackle the issue of Taiwan. However, it was first put into real practice to resolve the issue of Hong Kong; ${ }^{58}$ what's more, it must be understood in the broader context of China's grand project of national unification. ${ }^{59}$ As the expiration date of the Second Convention of Peking (1898) was fast approaching, London felt it was both necessary and timely to test the attitudes of Beijing regarding the issue of Hong Kong. Furthermore, the uncertainty of leases by the colony government of the city also provided the impetus for resolving Hong Kong's future. ${ }^{60}$ In September 1982, British Prime Minister Margaret Thatcher paid a state visit to Beijing, and the Chinese leader Deng Xiaoping said that reintegrating Hong Kong into China could be resolved through a policy of OCTS. ${ }^{61}$

During the 1982 China visit, the Iron Lady Thatcher insisted on the validity of the "three major treaties" involving Hong Kong, which was perhaps a great negotiating strategy. Thatcher first relied upon the long-established treaty law principle pacta sunt servanda, ${ }^{62}$ arguing that Britain could only return the New Territory, not including Kowloon Peninsula and Hong Kong Island, to China. Then, she proposed that after the transfer of sovereignty to China, Britain could still exercise a kind of administration for the continued success of the city. ${ }^{63}$ Next, Thatcher raised the military issue, requesting no Chinese garrison in Hong Kong. All those proposals were eventually rejected by the Chinese government based on three counterclaims. First, the "three major treaties" regarding Hong Kong shall be judged as unequal; they are per se null

\footnotetext{
${ }^{54}$ Standing Committee of the National People's Congress of the People's Republic of China, Message to the Compatriots in Taiwan (January 1, 1979).

${ }^{55}$ Guiguo Wang \& Priscilla M. F. Leung, One Country, Two Systems: Theory into Practice, 7 PAC. RIM L. \& Pol'y J. 279, 282 (1998).

${ }^{56}$ Albert H. Y. Chen, A Tale of Two Islands: Comparative Reflections on Constitutionalism in Hong Kong and Taiwan, 37 H.K. L.J. 647, 648 (2019).

57“One China, Better System” was strongly endorsed by Mr. Chen Changwen, who was the former secretary of the Straits Exchange Foundation. See Arthur Waldron, One China Gets MFN, The Other Deserves GATT, WALL STREET J., May 29, 1991 ("The meeting between C.V. Chen and Wu Xueqian suggests how much the psychological equation between the two Chinas has shifted. On the vexing issue of whether Beijing is the 'central' government and Taipei a 'local' one, Mr. Chen said the issue is not one of territorial size or population but of system. The choice, he said, has to be made by the Chinese people.").

${ }^{58}$ GitTings, supra note 8 , at 13 .

${ }^{59}$ In December 1981, during a meeting of the Politburo of Chinese Communist Party, a decision was made.

${ }^{60}$ GitTings, supra note 8 , at 12 .

${ }^{61}$ Wang \& Leung, supra note 55, at 293.

${ }^{62}$ Vienna Convention on the Law of Treaties art. 26, May 23, 1969, 1155 U.N.T.S. 331 [hereinafter VCLT].

${ }^{63}$ Hong Kong at that time was the world's third largest financial and gold trading center after New York City and London, and the city was also the source of one-third of the foreign currency earned by China. See British White Paper, Recent Developments - The Joint Declaration of the Government of the United Kingdom of Great Britain and Northern Ireland and the Government of the People's Republic of China on the Question of Hong Kong, 26 HARV. INT'L L.J. 249, 252-53 (1985).
} 
and void. ${ }^{64}$ Second, the revert of sovereignty must include China's governance and administration over the city; "Chinese sovereignty, British administration" is groundless. Third, the military garrison in Hong Kong is part of China's sovereignty, and it is essential to preserve the security of the city. On September 24, 1982, Deng Xiaoping said to Thatcher that there were three major issues on the table: (1) Sovereignty; (2) how to run Hong Kong after 1997; and (3) how to ensure stability and prosperity before the transfer of sovereignty. As for the first issue, Deng decisively said that sovereignty was not subject to negotiation, and China must get back its sovereignty over all parts of Hong Kong, including New Territory, Kowloon Peninsula, and Hong Kong Island. For the second issue, Deng said in principle that the existing political and economic institutions and Hong Kong's legal institutions could remain unchanged with some necessary revisions. The capitalistic system would be reserved. For the third issue, Deng's concern was the fifteen years of transition during which China would prepare the alternative if the worst scenario of insurgency happened. ${ }^{65}$

The Sino-British negotiation process can be roughly divided into two phases. The first phase, ranging from September 1982 to June 1983, set the agenda and cleared the relevant procedural issues. The second phase, ranging from July 1983 to September 1984, mainly aimed at the draft of the Joint Declaration. ${ }^{66}$ When the Sino-British negotiation was on its way, China also adopted the fourth Constitution in December 1982, Article 31 of which contained a provision that Special Administrative Regions ("SARs") may be established by the National People's Congress ("NPC"). ${ }^{67}$ This constitutional provision legitimized future SARs and provided the fundamental legal basis for ad hoc constitutional arrangements. ${ }^{68}$ After twenty-two rounds of negotiations, the Joint Declaration ${ }^{69}$ was finalized and formally signed on December 19, 1984, during another state visit to Beijing by Thatcher. ${ }^{70}$ The 1984 Joint Declaration, consisting of eight paragraphs and three annexes is an international treaty. ${ }^{71}$ Because it was not a self-executing treaty, China's NPC ratified it on April 10, 1985, ${ }^{72}$ while the U.K. Parliament passed it by adopting the Hong Kong Act of $1985^{73}$ on April 4, 1985. The Joint Declaration finally came into force on May 27, 1985.

\footnotetext{
${ }^{64}$ VCLT at art. 52; Katherine A. Greenberg, Hong Kong's Future: Can the People's Republic of China Invalidate the Treaty of Nanking as an Unequal Treaty, 7 Fordham INT'L L.J. 534 (1983); Douglas W. Lee, Hong Kong 1982-1984: Irredentism in the Chinese Practice of International Law, 1 InT'L Legal Persp. 3, 22-23 (1987).

${ }^{65}$ Deng Xiaoping, Our Basic Position Towards the Issue of Hong Kong, in Selected Landmark Literature Concerning One Country, Two Systems 8-9 (Party Literature Research Center of the CPC Central Committee ed., 1997). [邓小平: 《我 们对香港问题的基本立场》, 载中共中央文献研究室编: 《一国两制重要文献选编》, 中央文献出版社, 1997 年版, 第89 页。].

${ }^{66}$ Chinese Academy of Social Sciences Institute of Law, One Country, Two Systems and Hong Kong Basic Law, 19 CHINESE J. L. 5 (1997). [中国社科院法学研究所课题组 : 《“一国两制”与香港基本法》, 《法学研究》1997年第4期, 第5页。].

${ }^{67}$ H. Y. Chen, supra note 56, at 659; Neoh, supra note 5, at 325.

${ }^{68}$ Han Dayuan, The Role of Constitutional Law in the Drafting of the Basic Law of Hong Kong: Commemorating the 20th Anniversary of the Implementation of the Basic Law of Hong Kong, 39 MoD. LAw SCI. 5 (2017). [韩大元 : 《论 <宪法 $>$ 在 $<$ 香港特别行政区基本法>制定过程中的作用——纪念《香港特别行政区基本法》实施20周年》, 《现代法学》2017 年第5期，第5页。].

${ }^{69}$ Joint Declaration of the Government of the United Kingdom of Great Britain and Northern Ireland and the Government of the People's Republic of China on the Future of Hong Kong, Sept. 26, 1984, 23 I.L.M. 1366 [hereinafter 1984 Joint Declaration]. See also Joint Declaration of the Government of the United Kingdom of Great Britain and Northern Ireland and the Government of the People's Republic of China on the Question of Hong Kong with Annexes, 5 INT'L TAX \& BUS. L. 424 (1987).

${ }^{70}$ GitTings, supra note 8 , at 15 .

${ }^{71} I d$. at 18. See also Patricia Homan Palumbo, Analysis of the Sino-British Joint Declaration and the Basic Law of Hong Kong: What Do They Guarantee the People of Hong Kong after 1997, 6 ConN. J. INT'L L. 667, 691 (1991).

${ }^{72}$ Decision on the Ratification of Joint Declaration of the Government of the United Kingdom of Great Britain and Northern Ireland and the Government of the People's Republic of China on the Future of Hong Kong (promulgated by the Third Session of the Sixth National People's Congress, effective Apr. 10, 1985).

${ }^{73}$ The United Kingdom passed the Hong Kong Act 1985, which provided that "as from July 1, 1997, Her Majesty shall no longer have sovereignty or jurisdiction over any part of Hong Kong.” See Neoh, supra note 5, at 327.
} 


\section{The Making of Hong Kong Basic Law}

After concluding the Joint Declaration, then came the next big issue for China-the drafting of the Hong Kong Basic Law. The drafting process was a lengthy one that started in 1985 and ended in 1990 by China's NPC. ${ }^{74}$ Senior Chinese scholars categorized the drafting process into four stages: (1) A preparing stage from July 1985 to April 1986; (2) a consulting stage from May 1986 to April 1988; (3) a formulating stage from May 1988 to January 1989; and (4) a ratifying stage from February 1989 to April 1990. ${ }^{75}$ The establishment of the Basic Law Drafting Committee ("BLDC") on April 10, $1985^{76}$ marked a formal inception for the drafting process. Because it was created by a Chinese congressional resolution, commentators thus held that the drafting of the Basic Law was essentially a Chinese domestic affair. ${ }^{77}$ The similar process was largely duplicated for Macau. ${ }^{78}$ The name list of the members of the BLDC was adopted by a separate resolution on June 18, 1985. There were fifty-nine members in the committee, including twenty-three members from Hong Kong who were prominent businessmen and leading professionals. ${ }^{79}$ Moreover, the Basic Law Consultative Committee ("BLCC") was established under the auspices of the BLDC with 180 members. Unlike the BLDC, those members of the BLCC were all from Hong Kong and were mostly big names.

The BLDC was headed by Mr. Ji Pengfei (1910-2000) who simultaneously served as Director of Hong Kong and Macau Affairs in the State Council of China from 1982 to 1990. When the BLDC was ready to function, Ji Pengfei delivered a speech at the opening ceremony of the first meeting as follows:

The Basic Law Drafting Committee is the working organ established by the National People's Congress for drafting the Basic Law of the Hong Kong Special Administrative Region; it is responsible to the National People's Congress, and when the National People's Congress is not in session, it is responsible to the Standing Committee of the National People's Congress. ${ }^{80}$

In his explanation, Ji Pengfei said that the purpose of the BLDC was to convey to the Standing Committee "fully the opinions of the people from all walks of life in Hong Kong." 81 After kicking off, the following four years of the drafting process proved to be unusual in many respects. There were international concerns about the Basic Law draft. The draft process also underwent historical events such as the end of the Cold War and the June Fourth Incident in 1898. Within the framework of legislative procedure, there were serious divergences of opinions toward the draft. Many of the controversies in the drafting process actually sowed the seeds for future political and legal challenges after 1997.

First, when turning OCTS into law, there were significant conflicts of legal norms between the two systems. Many of the conflicts were direct results of the differences between the Chinese

\footnotetext{
${ }^{74}$ Albert H. Y. Chen, The Basic Law and the Development of the Political System in Hong Kong, 15 AsIA PAC. L. REV. 19, $20-$ 21 (2007).

${ }^{75}$ Dayuan, supra note 68, at 5-6 [韩大元：《论 <宪法 $>$ 在 <香港特别行政区基本法 $>$ 制定过程中的作用一一纪念 《香港特别行政区基本法》实施20周年》，《现代法学》2017年第5期，第5页。].

${ }^{76}$ Decision of the Third Session of the Sixth National People's Congress on Establishing the Drafting Committee of the Basic Law for Hong Kong Special Administrative Region of the People's Republic of China (promulgated by the Third Session of the Sixth National People's Congress, effective Apr. 10, 1985).

${ }^{77}$ Joseph Y.S. Cheng, Draft Basic Law: Messages for Hong Kong People, 5 ConTEMP. Asian Stud. 7, 8 (1988).

${ }^{78}$ Decision of the National People's Congress on Establishing the Drafting Committee for the Basic Law of Macao Special Administrative Region of the People's Republic of China (promulgated by the First Session of the Seventh National People's Congress, effective Apr. 13, 1988).

${ }^{79}$ Cheng, supra note 77. The exact names can be found at Law Yearbook Of China 1987-1997 1221 (Sun Wanzhen ed. 1998).

${ }^{80}$ Cheng, supra note 77 , at $7,9$.

${ }^{81}$ Yash Ghai, The Intersection of Chinese Law and the Common Law in the Hong Kong Special Administrative Region: Question of Technique or Politics?, 37 H.K. L.J. 363 (2007).
} 
socialist legal tradition and the common law tradition. Above all, those conflicts lead to a fundamental one: To what extent can the Basic Law survive Chinese constitutionality? Due to the promise of keeping capitalist society in Hong Kong, the Basic Law is said to conflict with two of the most important articles of the Chinese Constitution: Article 1 of the 1982 Constitution provided a socialist system ${ }^{82}$ and Article 2 of the 1982 Constitution required uniformity of the Chinese socialist legal system. ${ }^{83}$ Furthermore, Cambridge Professor William Wade added that "in the eyes of an English lawyer, the Chinese constitution and the Basic Law would contradict with each other." 84

Second, the BLDC had to be confronted with the very conception of basic law as to what sense the term "basic law" is used. Is it the same as the German Basic Law (Grundgetzbuch) or another version of Israel's Basic Laws by the Knesset? In a legal-norm or system, there are norms that are referred to as "top norms," "apex norms," or more often as basic norms (Grundnormen). In Kelsen's terminology, ${ }^{85}$ such basic norms afford validity to the whole system, while in Hart's terminology, ${ }^{86}$ they are "rules of recognition." ${ }^{87}$ The basic norm, according to Kelsen, is a "fiction" in the terminology of Vaihinger's Philosophiede des als-ob: To ground the validity of the norms forming a positive moral or legal order. ${ }^{88}$ In Israel's formative era, disagreements from top to bottom prevented the adoption of a written constitution. ${ }^{89}$ The Basic Laws by Harari Resolution did not mean a constitution, but rather a set of laws that did not differ from other laws. ${ }^{90}$ In terms of Article 62(3) of the PRC's 1982 Constitution, the Chinese distinguish basic laws and non-basic laws and treat civil law and criminal law also as basic law. Later research shows that the Basic Law of Hong Kong is not a law with constitutional value within the hierarchy of sources of the PRC, and no official decision or legislation refers to the "Hong Kong Basic Law" as one of the laws of Article 62(3)..$^{91}$

Third, what is the nature, degree, and guarantee of the "high degree of autonomy"? On April 4, 1990, in debating the draft of the Basic Law, the Hong Kong Legislative Council ("LegCo") passed a motion proposed by Mr. Martin Lee. It was mentioned that there were three paramount objectives of the Basic Law: (1) the Basic Law must represent the views of and be fully acceptable to the people of Hong Kong; (2) it must accord with the letter and spirit of the Joint Declaration; and (3) it must provide Hong Kong with an effective and workable system of government. ${ }^{92}$ However, the draft did not elaborate the specifics of "high degree of autonomy," and it was not clear, crucially, whether it was to be of the legal or of the political kind..$^{93}$

Fourth, how should the Basic Law be interpreted and to whom is such power vested? This is an issue addressed by Article 169 of the 1988 draft and finally incorporated into Article 158 of the Basic Law. ${ }^{94}$ Both the draft and final version of the Basic Law made the NPCSC the ultimate

\footnotetext{
${ }^{82}$ As for the 2018 Chinese Constitutional Amendment, the leadership of the CCP was for the first time formally added to Article One.

${ }^{83}$ Patricia Homan Palumbo, Analysis of the Sino-British Joint Declaration and the Basic Law of Hong Kong: What Do They Guarantee the People of Hong Kong After 1997, 6 ConN. J. INT'L L. 667, 701-02 (1991).

${ }^{84}$ William Wade, Opinion on the Draft Hong Kong Basic Law, 5 ConTEMP. Asian STud. 81, 83 (1988).

${ }^{85}$ Hans Kelsen, Pure Theory of Law 193, 328 (1967).

${ }^{86}$ H. L. A. Hart, The Concept of Law 94, 95 (2d ed. 1994).

${ }^{87}$ Torstein Eckhoff, Notion of Basic Norm(s) in Jurisprudence, 19 SCANDINAVIAn STUd. L. 121, 123 (1975).

${ }^{88}$ J. W. Harris, The Basic Norm and the Basic Law, 24 H.K. L.J. 207, 210-11 (1994).

${ }^{89}$ Joshua Segev, Who Needs a Constitution-In Defense of the Non-Decision Constitution-Making Tactic in Israel, 70 ALB. L. REV. 409, 423 (2007).

${ }^{90}$ Id. at 425. See also Peter Elman, Basic Law: The Government (1968), 4 IsR. L. Rev. 242, 243 (1969).

${ }^{91}$ Miguel Angelo Loureiro Manero de Lemos, The Basic Laws of Hong Kong and Macau As Internationally Shaped Constitutions of China and the Fall Off of "One Country, Two Systems," 27 Tul. J. INT'L \& Comp. L. 277, 299 (2019).

${ }^{92}$ Hong Kong Legislative Council Debate on the Basic Law of the Hong Kong Special Administrative Region, 23 CHINESE L. \& Gov'T 66, 67 (1990).

${ }^{93}$ Wade, supra note 84 , at $81-82$.

${ }^{94}$ Draft Basic Law of the Hong Kong Special Administrative Region of the People's Republic of China, 22 CHINESE L. \& GOV'T 12, 34 (1989); Basic Law at art. 158.
} 
arbiter when interpreting the Basic Law, but it "shall consult" the Basic Law Committee "55 "before giving an interpretation." "Why should the Basic Law make NPCSC the supreme "interpreter" on Basic Law? And why should the Court of Final Appeal, as the court of last resort, not have the last word on the interpretation of the Basic Law? China's constitutional arrangements of SARs, Hong Kong, and Macau and the constitution-making of Hong Kong resulted from very different entities. A court of final appeal was one of the deals made during the Sino-British negotiation, ${ }^{97}$ and this can be understood as a Chinese concession. ${ }^{98}$ Lacking a tradition of judicial review under the Chinese socialist legal system, perhaps it is more proper to conceive of the notion that the one who made it knows better than others.

In April 1988, the Basic Law draft, containing 170 articles and two annexes, was revealed for solicitation of public opinions. ${ }^{99}$ On February 21, 1989, a revised draft, consisting of 159 articles and three annexes, was formally released by the Standing Committee of the NPC. ${ }^{100}$ On April 4, 1990, the final draft was adopted by the NPC with 160 articles and three annexes. ${ }^{101}$ Later records show that the BLDC and BLCC had intensive conferences, and their dedication to the draft was highly praised by the Chinese officials.

\section{Hong Kong's Two-Decade Implementation of OCTS}

After the handover, the pre-existing common law, the text of the Basic Law, and the NPC's Standing Committee's interpretations of the Basic Law constitute the entirety of the Basic Law. ${ }^{102}$ The notion of OCTS embedded in the Basic Law is a unique political idea in the course of China's post-1949 history. Most constitutional theorists and commentators in both mainland China and Hong Kong generally trace back the big idea to Chinese paramount leader Deng Xiaoping, who transformed China across the 1980s. Deng famously formulated the idea of OCTS in June 1984 during a meeting with prominent Hong Kong business people led by Sir Sze-yuen Chung (1917-2018) as the following: "We are pursuing a policy of 'One Country, Two Systems.' More specifically, this means that within the PRC, the mainland with its one billion people will maintain the socialist system, while Hong Kong and Taiwan continue under the capitalist system."103

One month later, Deng further elaborated OCTS during another meeting with British Foreign Secretary Sir Geoffrey Howe and said:

The idea was first presented as a means of settling the Taiwan and Hong Kong questions. The socialist system on the Mainland, with its population of one billion, will not change, ever. But

\footnotetext{
${ }^{95}$ According to Rayson Huang, Convenor of the Subgroup on Central-Local Relations of the Basic Law Drafting Committee, the Basic Law Committee was meant to countervail, in case of conflict, the Basic Law's overarching emphasis on "One China." See Eric C. Ip, Prototype Constitutional Supervision in China: The Lessons of the Hong Kong Basic Law Committee, 10 AsIAN J. CoMp. L. 323, 328 (2016).

${ }^{96}$ Basic Law at art. 158.

${ }^{97} 1984$ Joint Declaration at para. 3(3)

${ }^{98} \mathrm{Id}$.

${ }^{99}$ Draft Basic Law, supra note 94.

${ }^{100}$ Draft Basic Law of the Hong Kong Special Administrative Region of the People's Republic of China, 3 GAZETTE ST. CounCIL CHINA (1989).

${ }^{101}$ Decision of the National People's Congress Approving the Proposal by the Drafting Committee for the Basic Law of the Hong Kong Special Administrative Region on the Establishment of the Committee for the Basic Law of the Hong Kong Special Administrative Region Under the Standing Committee of the National People's Congress (promulgated by the Third Session of the Seventh National People's Congress, effective Apr. 4, 1990).

${ }^{102}$ Zhenmin Wang, Relationship Between the Chinese Central Authorities and Regional Governments of Hong Kong and MacaO: A Legal Perspective 373 (2019).

${ }^{103}$ Deng Xiaoping, On Constructing Socialism with Distinctive Chinese Features [Jianshe you ZhongGuo tese DI SHEHUI ZHUYI] 41-42 (1987).
} 
in view of the history of Hong Kong and Taiwan and of their present conditions, if the continuation of the capitalist system there is not guaranteed, prosperity and stability cannot be maintained, and peaceful reunification of the Motherland will be out of the question. Therefore, with regard to Hong Kong, we propose first of all to guarantee that the current capitalist system and way of life will remain unchanged for 50 years after $1997 .{ }^{104}$

As we all know, the OCTS formula is reflected both in the 1984 Joint Declaration and the Hong Kong Basic Law. ${ }^{105}$ The framers of the Basic Law had done the unprecedented work of translating the political formula into legal terms, mitigating the suspicion and credibility problem. ${ }^{106}$ However, it is in this context that the nature of OCTS needs to be further carefully examined on a constitutional level. Zhu Guobin provides two main interpretive paradigms for this. First, he argues that OCTS is a political concept which ultimately guides and leads to the creation of Basic Law. Second, he treats OCTS as a legal and constitutional norm which basically provides the fundamental principles for China to handle the very complex relationship between the central and local governments. ${ }^{107}$ Admittedly, both the political and legal natures co-exist under the OCTS formula. It is more important to analyze the nature of the formula from a wider perspective that is articulated by later constitutional cases from Hong Kong's judiciary.

Under the Chinese constitutional framework, Hong Kong's laws differ from the mainland system in that they are sui generis. It is hard to say that Hong Kong's laws are purely common law in every respect, ${ }^{108}$ as the facts show that the Hong Kong Basic Law was not drafted by common law lawyers. It was drafted in the Chinese language with an official English version. However, the Chinese version takes precedence in case of discrepancies. ${ }^{109}$ Hong Kong courts later affirmed the fundamental nature of the Basic Law as a unique document with at least three dimensions: International, domestic, and constitutional. ${ }^{110}$ Chief Justice Chan of the High Court stated in HKSAR v. Ma WK David that "The Basic Law is not only a brainchild of an international treaty, the Joint Declaration, it is also a national law of the PRC and the constitution of the HKSAR."111 In the $\mathrm{Ng} \mathrm{Ka} \mathrm{Ling} \mathrm{case,} \mathrm{Chief} \mathrm{Justice} \mathrm{Li} \mathrm{of} \mathrm{the} \mathrm{Court} \mathrm{of} \mathrm{Final} \mathrm{Appeal} \mathrm{held} \mathrm{that} \mathrm{the} \mathrm{Basic} \mathrm{Law} \mathrm{became}$ the constitution of the Hong Kong Special Administrative Region ("HKSAR") upon its establishment on July 1, 1997 when China resumed the exercise of sovereignty over Hong Kong. ${ }^{112}$ Although there have been different interpretation of OCTS, much of the theoretical understanding heavily relies upon Justice Chan's legal reasoning in HKSAR v. Ma WK David.

The legal nature of OCTS must be analyzed in a larger Chinese legal-political context with broader understanding of the delegated autonomy of Hong Kong. First and foremost, the OCTS formula is a Chinese proposal aimed at national unification that was accepted by the British as it was crystallized in the 1984 Joint Declaration. Notwithstanding the fact that the draft

\footnotetext{
${ }^{104}$ Deng Xiaoping, Deng Xiaoping on the Question of Hong Kong 12 (1993).

${ }^{105}$ GitTings, supra note 8 , at 37-38.

${ }^{106}$ Eric C. Ip, Prototype Constitutional Supervision in China: The Lessons of the Hong Kong Basic Law Committee, 10 AsIAN J. Comp. L. 323, 326-27 (2016).

${ }^{107}$ Zhu Guobin, The Composite State of China Under One Country Multiple Systems: Theoretical Construction and Methodological Considerations, 10 ICON 272, 274-77 (2012).

${ }^{108}$ See Yu Xingzhong, Subsidiarity, Authority and Constitutional Experimentalism in Hong Kong, 49 H.K. L.J. 315, 316 (2019).

${ }^{109}$ Hong Kong v. Ma Wai Kwan David \& Others, [1997] 2 H.K.C. 315, para. 14 (C.A.) [hereinafter Ma Wai Kwan David Case].

${ }^{110}$ It reflects a treaty made between two nations. It deals with the relationship between the Sovereign and an autonomous region that practices a different system. It stipulates the organizations and functions of the different branches of government. It sets out the rights and obligations of the citizens. It must also be borne that being the background and features of the Basic Law, it is obvious that there will be difficulties in the interpretation of its various provisions. See Ma Wai Kwan David Case at para. 14.

${ }^{111} I d$. at para. 13 .

${ }^{112} \mathrm{Ng}$ Ka Ling v. Dir. of Immigration, [1999] 2 H.K.C.F.A.R. 4, para. 74 (C.F.A.) [hereinafter Ng Ka Ling Case].
} 
Basic Law was debated in Hong Kong's pre-1997 legislature, the sovereign destiny of Hong Kong was substantially predetermined without Hong Kong as an independent party to the Sino-British deal. Second, largely different from other constitutions, the Basic Law is a document with delegation of autonomy to a special administrative region, not a sovereign act of self-definition. ${ }^{113}$ Third, concerning the relationship between the Joint Declaration and Basic Law, as Professor Owen M. Fiss correctly put it, the Joint Declaration would not entrench the Basic Law if the treaty was to be enforced against China, and it does not prevent the Basic Law from being repealed or modified though simple legislation. ${ }^{114}$ Since its inception, the two-decade implementation of the Basic Law echoes many of the opinions advanced by Professor Owen M. Fiss. Some Hong Kong constitutional scholars have developed a game-analytical framework to analyze the constitutional development of Hong Kong after $1997^{115}$ while others have provided a political development paradox of "semi-democracy" to evaluate the implementation of the Basic Law. ${ }^{116}$ Those analytical frameworks stirred many intellectual aspirations, and I would like to further offer a trimester analysis by focusing on the constitutional development of OCTS: (1) The first period spans from 1997 to 2002, which reflects what the Chinese called "the separation of river water and well water"; (2) the second period is one of growing constitutional controversies ranging from the Article 23 event in 2003 to the Occupy Central Movement of 2014; (3) the third period begins with post-Occupy politics and extends to the ongoing constitutional crisis in Hong Kong. I will illustrate some of the watershed events from those three periods. This history offers different, yet equally important, lessons on the rise and fall of China's constitutional commitments towards OCTS.

\section{The Separation of River Water and Well Water}

Roughly from 1997 to 2002, there was a general trend that showed people of Hong Kong largely embraced OCTS. Local residents mostly held positive attitudes towards China's resumption of sovereignty during the early years; they shared the pride of the Chinese success whenever China won a prize during international competitions, such as the Sydney Olympics. This was a period of Chinese patriotism that trumped parochialism. One may show contrary evidence of the discontinuity of the normal constitutional order, such as the border crisis and enormous conflicts between mainland immigrants and local Hong Kong residents, but the general trend shows that these conflicts have not reached a level of real constitutional divorce of the two systems. Despite some notable controversial cases regarding right of abode, such as the $\mathrm{Ng} \mathrm{Ka} \mathrm{Ling} \mathrm{case}$ (1999) ${ }^{117}$ and the Chong Fung Yuen case (2001), ${ }^{118}$ the early years in the history of HKSAR are generally regarded as a relatively peaceful and smooth period of establishing post-colonial constitutional order and implementing OCTS. Chinese scholars generally hold the view that the Basic Law implements the OCTS policy and turns the policy from a scientific concept into vivid reality. ${ }^{119}$ Professor Albert H.Y. Chen, a leading Hong Kong constitutional scholar, also pointed out that during these early years, elections of the Chief Executive and the Legislative Council (LegCo) run on their normal tracks in accordance with the law. ${ }^{120}$

\footnotetext{
${ }^{113}$ Owen M. Fiss, Hong Kong Democracy, 36 Colum. J. Transnat'l L. 493, 497 (1998).

${ }^{114} I d$. at 498.

${ }^{115}$ Benny Y.T. Tai, Round Three of Hong Kong's Constitutional Game: From Semi-Democracy to Semi-Authoritarianism, 49 H.K. L.J. 335 (2019); Y.T. Tai, supra note 9, at 503.

${ }^{116}$ Albert H. Y. Chen, The Hong Kong Basic Law and the Limits of Democratization Under One Country Two Systems, 50 INT'L L. 69 (2017); Michael C. Davis, Constitutionalism and the Politics of Democracy in Hong Kong, 30 FLETCHER F. WORLD AfF. 165 (2006); H. Y. Chen, supra note 74, at 19.

${ }^{117} \mathrm{Ng}$ Ka Ling Case.

${ }^{118}$ Dir. of Immigration v. Chong Fung Yuen, [2001] 4 H.K.C.F.A.R. 211 (C.F.A.) [hereinafter Chong Fung Yuen Case]

${ }^{119}$ Xiao Weiyun, The Hong Kong Basic Law: A Masterpiece of Creative Legislation, 3 CHINA L. 87, 89-90 (1995); Wang \& Leung, supra note 55, at 293.

${ }^{120}$ Chen, supra note 116 , at 74 .
} 
Unlike the constitutional model of German unification under which the East was absorbed into the West in light of Article 143 of the German Basic Law (Grundgesetz), ${ }^{121}$ OCTS emerged as a novelty in the context of the larger international community and the Chinese proudly characterize OCTS as an "unprecedented" invention and treat it as a unique contribution to solve historical territorial issues. Because there were no precedents to follow, both mainland China and Hong Kong had to set foot on a new journey. For the early years, the Chinese leader Jiang Zemin adopted a policy of "Separating River Water from Well Water," under which the "river water" represents Guangdong's natives and "well water" refers to Hong Kong natives. ${ }^{122}$ A further survey on the origin of this analogy shows that it was during the mid-1980s that Chinese leaders asserted, "the well water does not interfere with the river water." 23 The purpose of the assertion for the top Chinese leaders was to prevent Hong Kong from being a "base of subversion" towards socialist China. ${ }^{124}$ For the early years following the transfer of sovereignty, Chinese leaders generally kept their promise not to interfere with Hong Kong affairs with exceptions for sovereign matters. Research shows that the NPC slated only 1.3 percent of 1,760 laws and regulations in Hong Kong for expiration at midnight of June 30, 1997. ${ }^{125}$ Prior common law in Hong Kong that does not contravene the Basic Law continues to operate in the city.

Confronted with the potential and real conflicts of the capitalistic common law legal system in Hong Kong and the socialist civil law system in mainland China, one may well question the policy of "Separating River Water from Well Water" because the two kinds of water will inevitable converge at some point. Hong Kong constitutional scholar Johannes Chan argues that the Basic Law itself provides an interface of the two systems and faithful implementation of the Basic Law would lead to a high degree of autonomy in Hong Kong. ${ }^{126}$ In HKSAR v. Ma Wai Kwan David (1997), Hong Kong court was directly confronted with the question of whether offenses under the previous common law of conspiracy to pervert the course of public justice were part of the laws of the newly established HKSAR. The respondents contended that the common law had not survived the change of sovereignty on July 1, 1997, and thus the amended indictment should be quashed. ${ }^{127}$ Because the Hong Kong Basic Law did not provide for automatic adoption of the laws previously in force and the legal system in Hong Kong after July 1, 1997, ${ }^{128}$ the Government thus relied on the Hong Kong Reunification Ordinance that was passed by the Provisional LegCo ("PLC") on July 1, 1997. ${ }^{129}$ After the failure of the common law argument during the legal battle, the defendants continued to challenge the lawfulness of the PLC based on the fact that the PLC was not itself an elected body as required by Article 68 of the Basic Law, Annex II of the 1984 Joint Declaration, and the April 4, 1990 Decision of the NPC. ${ }^{130}$ After referring to legislative history and careful constitutional analysis, the court concluded that the PLC, in accordance with the NPC Decision of April 4, 1990, was part of the arrangements and methods for establishing the first LegCo. In addition, the court held that the legality or validity of laws made by sovereign power - the NPC - was not open to challenge in the Hong Kong courts, but the court did have the jurisdiction to say whether such sovereign acts exist or not. ${ }^{131}$

\footnotetext{
${ }^{121}$ Matthew W. Pile, Ten Years of Basic Law Amendments: Developing a Constitutional Model of German Unification, 34 VAND. J. TRANSNAT'L L. 633, 648 (2001).

${ }^{122}$ Tahirih V. Lee, Mixing River Water and Well Water: The Harmonization of Hong Kong and PRC Law, 30 LOY. U. CHI. L.J. 627 (1999).

${ }^{123}$ Davis, supra note 116 , at 173.

${ }^{124} I d$.

${ }^{125}$ Lee, supra note 122 , at 633 .

${ }^{126}$ Johannes Chan, Basic Law and Constitutional Review: The First Decade, 37 H.K. L.J. 407, 408 (2007).

${ }^{127}$ J. Kate Burkhart, HKSAR v. Ma Wai Kwan David \& Ors: A Step in the Right Direction, 6 Tul. J. INT'L \& COMP. L. 609 (1998).

${ }^{128}$ Article 160 of the Hong Kong Basic Law states, "the laws previously in force in Hong Kong shall be adopted as laws of the Region except for those which the Standing Committee of declares to be in contravention of the Law."

${ }^{129} \mathrm{Ma}$ Wai Kwan David Case at para. 214.

${ }^{130}$ Burkhart, supra note 127.

${ }^{131} \mathrm{Ma}$ Wai Kwan David Case at paras. 214-15.
} 
HKSAR v. Ma Wai Kwan David (1997) was the first constitutional case for HKSAR that posed serious challenges for the co-existence of the two systems. Nevertheless, the Tung Chee-Hwa administration (1997-2005) was lucky to barely go through those constitutional challenges and the continuity of the legal order after the handover therefore survived for the early years. As Chief Justice Chan of the High Court stated in HKSAR v. Ma Wai Kwan David:

[T] he essence of these policies is that the current social, economic, and legal systems in Hong Kong will remain unchanged for 50 years. The purpose of the Basic Law is to ensure that these basic policies are implemented and that there can be continued stability and prosperity for the HKSAR. ${ }^{132}$

The early years after the handover are remembered as the period of "maximum autonomy" for Hong Kong, largely due to China's policy of "Separation of River Water and Well Water." This history might well be described as the honeymoon years between the mainland and Hong Kong.

\section{Article 23 Controversy}

A major turning point in the post-1997 history of Hong Kong was the Hong Kong government's attempt to enact a national security law for the purpose of implementing Article 23 of the Basic Law that requires the HKSAR to enact laws on treason, secession, sedition, subversion, and protection of state secrets. ${ }^{133}$ In order to fulfill its constitutional duty, the Tung Chee-Hwa administration published the Consultation Document on Proposals to Implement Article 23 of the Basic Law on September 24, 2002. During the three-month consultation period, Tung Chee-Hwa's proposal caused much public anxiety. People doubted whether the Hong Kong and Beijing governments had the sinister intention of curtailing human rights in Hong Kong and extending mainland standards regarding matters such as subversion or the theft of state secrets to Hong Kong. ${ }^{134}$ In February 2003, the Tung Chee-Hwa administration formally sent the National Security (Legislative Provisions) Bill to the LegCo for debates, which culminated in a massive protest of half a million people on July 1, 2003. Under blistering attacks and enormous pressure, the CE eventually withdrew the bill from the LegCo on September 5, 2003. ${ }^{135}$

There are both pros and cons for Article 23 legislation in mainland China and Hong Kong. A fundamental critique of Article 23 was based on Article 3(5) of the 1984 Joint Declaration, which ensures rights and freedoms including, inter alia, those of the person, speech, press, and association. ${ }^{136}$ Many Hong Kong academics and lawyers based their critique of Article 23 on the principle of minimum legislation in determining whether the restriction on human rights could be justifiable. ${ }^{137}$ Others have criticized the proposed legislative bill from various perspectives, such as criminal law, basic law interpretation, and ICCPR application. ${ }^{138}$ Protections for fundamental rights and

\footnotetext{
${ }^{132} I$ d. at para. 13 .

${ }^{133}$ Basic Law at art. 23.

${ }^{134}$ Albert H. Y. Chen, How Hong Kong Law Will Change When Article 23 of the Basic Law is Implemented, 33 H.K. L.J. 1, 6 (2003); Albert H. Y. Chen, The Rule of Law Under One Country, Two Systems: The Case of Hong Kong 1997-2010, 6 NAT'L Taiwan U. L. Rev. 269, 283 (2011); Benny Y.T. Tai, The Principle of Minimum Legislation for Implementing Article 23 of the Basic Law, 32 H.K. L.J. 579, 614 (2002); Tai, supra note 9, at 555.

${ }^{135} \mathrm{Bob} \mathrm{Hu}$, The Future of Article 23, 41 H.K. L.J. 431, 432 (2011).

${ }^{136}$ Inbal Sansani, The Threat of Article 23 to Civil Liberties in the Hong Kong Special Administrative Region, 10 HUM. RTs. BRIEF 28, 30 (2003).

${ }^{137}$ Yash Ghai, Derogations and Limitations in the Hong Kong Bill of Rights, in The Hong Kong BiLl of Rights: A Comparative Approach 19 (Johannes Chan \& Yash Ghai eds., 1993); Tai, supra note 9, at 555; Tai, supra note 134, at 588-90.

${ }^{138}$ H.L. Fu, Richard Cullen \& Pinky Choy, Curbing the Enemies of the State in Hong Kong-What Does Article 23 Require?, 5 J. CHINESE \& COMP. L. 45 (2002); Carole J. Petersen, National Security Offences and Civil Liberties in Hong Kong: A Critique of the Government's "Consultation" on Article 23 of the Basic Law, 32 H.K. L.J. 457 (2002).
} 
freedoms are guaranteed under Chapter III of the Basic Law, ${ }^{139}$ and Chief Justice Li's court has been consistently affirming that "freedoms are at the heart of Hong Kong's system." Such judicial opinions can be found in HKSAR v. Ng Kung Siu ${ }^{140}$ and Yeung May Wan v. HKSAR. ${ }^{141}$ However, the Beijing government and the pro-establishment camp in Hong Kong also provided major compelling arguments for the legislative bill. First, Article 23 of the Basic Law clearly mandates the HKSAR government for such a bill, and HKSAR bears an unfulfilled constitutional duty. Second, most jurisdictions around the world have had various even tougher national security laws and Hong Kong is no enclave. Third, it is exactly the legislative intent of Article 23 that Hong Kong should never become a base of subversion against the mainland socialist system. Last, a correct understanding of China's Hong Kong policy should put one country ahead of the two systems.

A closer look at the travaux préparatoires of the Basic Law suggests that the first draft of Article 23 (previously Article 22) ${ }^{142}$ had much broader and more ambiguous terms than any of the subsequent drafts, mandating that the HKSAR shall prohibit by law any act designed to undermine national unity or subvert the Central People's Government. The second draft was amended to say "the HKSAR shall enact laws on its own to prohibit any act of treason, secession, sedition or theft of state secrets." When the third draft of Article 23 was to be fixed, unprecedented political turmoil in the summer of 1989 broke out and the Tiananmen bloodshed incident was deemed a fundamental change of circumstances, since Beijing clearly sent a message to the BLDC that Hong Kong should not be used as a "subversion base" against the mainland. ${ }^{143}$ The final draft of Article 23, published in April 1990, nonetheless stipulates that the HKSAR "enact laws on its own to prohibit any act of treason, secession, sedition, and subversion against the Central People's Government, or theft of state secrets, to prohibit foreign political organizations or bodies from conducting political activities in the Region, and to prohibit political organizations or bodies of the Region from establishing ties with foreign political organizations or bodies." 144

The Article 23 controversy, as the history shows, marks the real watershed of the constitutional relationship between the mainland and Hong Kong. When the Chinese foreign minister Qian Qichen (1928-2017) expressed his wish for Article 23 legislation in 2002, he would not expect the subsequent reactions of the Hong Kong people. Since the Tung Chee-Hwa administration, there has been no further introduction of Article 23 legislation in Hong Kong until now. It seems to be far from certain that the harmonization of Hong Kong and PRC Law will happen in the near future. As Albert H.Y. Chen argues, the constitutional duty cannot be abdicated indefinitely. ${ }^{145}$ Article 23 legislation continues to serve as the touchstone on whether "Two Systems" can protect "One Country. ${ }^{146}$ Constitutional scholars widely held the view that since the watershed protest in 2003, Beijing began moving away from a policy that "gave more weight to the 'two system"” towards a new one which instead "gives more weight to 'one country." 147

\footnotetext{
${ }^{139}$ Yash Ghai, The Hong Kong Bill of Rights Ordinance and the Basic Law of the Hong Kong Special Administrative Region: Complimentarities and Conflicts, 1 J. CHINESE \& COMP. L. 30, 34-36 (1995).

${ }^{140}$ Hong Kong v. Ng Kung Siu, [1999] 3 H.K.L.R.D. 907 (H.C.).

${ }^{141}$ Yeung May Wan v. Hong Kong, [2005] 2 H.K.L.R.D. 212 (H.C).

${ }^{142}$ The Hong Kong Special Administrative Region shall prohibit by law any act designed to undermine national unity or subvert the Central People's Government. See Consultative Comm. for the Basic Law of the Hong Kong Special Administrative Region of the P.R.C., The Draft Basic Law of the Hong Kong Special Administrative Region of the P.R.C. (For Solicitation of Opinions), in Consultative Report vol. 5 195-202 (1988).

${ }^{143}$ See H.L. Fu \& Richard Cullen, National Security Law in Hong Kong: Quo Vadis - A Study of Article 23 of the Basic Law of Hong Kong, 19 UCLA PAC. Basin L.J. 185, 194-99 (2002); Tom Kellogg, Legislating Rights: Basic Law Article 23, National Security, and Human Rights in Hong Kong, 17 COLUM. J. Asian L. 307, 309-11 (2004).

${ }^{144}$ Sansani, supra note 136 , at 29.

${ }^{145}$ Chen, supra note 134 , at 285.

${ }^{146}$ Doreen Weisenhaus, Article 23 and Freedom of the Press: A Journalistic Perspective, in NATIONAL SECURITY AND FUNDAMENTAL Freedoms: Hong Kong's Article 23 Under Scrutiny 278 (Fu Hualing, Carole J. Petersen \& Simon N.M. Young eds., 2005).

${ }^{147}$ Jie Cheng, The Story of a New Policy, Hong Kong Journal (2009), http://www.hkbasiclaw.com/Hong\%20Kong\% 20Journal/Cheng\%20Jie\%20article.htm; GITTINGS, supra note 8, at 308.
} 


\section{Occupying Central Movement}

Hong Kong, either as a British colony or as a Chinese Special Administrative Region, has been striving to become a true democracy, and the issue concerning how Kong Hong should be governed thus becomes an unfinished democratic project. At the heart of this project lies the universal suffrage of both the CE and the LegCo. Both Articles 45 and 68 of the Basic Law address the selection of those two important institutions via election, and China approached it through pragmatic incremental methods which largely led to a later election crisis. In 2004, confronted with pressing needs for post-2007 elections of the CE and LegCo, the NPC issued a Basic Law interpretation regarding Articles 45, 68, and the two annexes, reaffirming "the principle of gradual and orderly progress." ${ }^{448}$ In 2005, due to the resignation of Tung Chee-Hwa, there were great differences of opinion on whether the new CE should serve the remainder of the term of his predecessor. The NPC thus issued another Basic Law interpretations regarding Article 46, ${ }^{149}$ stating, "in the event that the office of Chief Executive becomes vacant . . the term of office of the new Chief Executive shall be the remainder of the term of office of the previous Chief Executive." 150 Upon assuming office as Hong Kong's second CE in 2007, Donald Tsang initiated a public consultation process on elections by releasing the Green Paper on Constitutional Development, which was submitted to the NPCSC at the end of the year. ${ }^{151}$ In response, the NPCSC rendered a decision $^{152}$ that stated that, although the 2012 election of the CE and LegCo would not occur under conditions of universal suffrage, minor amendments to the election methodology of the CE could be proposed by the Hong Kong government. ${ }^{153}$ Meanwhile, the 2007 Decision vowed that the election of the CE in 2017 may be implemented by the method of universal suffrage, and the election of the LegCo may be implemented in the same way as that of the CE at a later stage. ${ }^{154}$

Following the victory of Mr. C.Y. Leung as the new CE after winning 689 votes in the 1200member Election Committee in 2012, Hong Kong's constitutional development underwent a series of difficulties. Donald Tsang, the former CE and President of the Executive Council ("ExCo"), was charged with one count of bribery and two further counts of misconduct in public office. ${ }^{155}$ The pro-democracy camp called for Mr. C.Y. Leung's impeachment based on Article 73(9) of the Basic Law and relevant provisions under the Legislative Council (Powers and Privileges) Ordinance. Though the impeachment turned out to be unsuccessful, it showed the tension between the new LegCo and CE. ${ }^{156}$ During C.Y. Leung's term, pro-democracy LegCo

\footnotetext{
${ }^{148}$ Interpretation by the Standing Committee of the National People's Congress Regarding Annex I(7) and Annex II(III) to the Basic Law of the Hong Kong Special Administrative Region of the People's Republic of China (promulgated by the 8th Meeting of the Standing Committee of the Tenth National People's Congress, effective Apr. 6, 2004).

${ }^{149}$ Basic Law at art. 46 ("The term of office of the Chief Executive of the Hong Kong Special Administrative Region shall be five years. He or she may serve for not more than two consecutive terms.").

${ }^{150}$ Interpretation by the Standing Committee of the National People's Congress Regarding the Second Paragraph in Article 53 of the Basic Law of the Hong Kong Special Administrative Region of the People's Republic of China (promulgated by the 15th Meeting of the Standing Committee of the Tenth National People's Congress, effective Apr. 27, 2005).

${ }^{151}$ Gregory S. Gordon, When One Country, Two Systems Meets One Person, One Vote: The Law of Treaties and the Handover Narrative through the Crucible of Hong Kong's Election Crisis, 16 MeLb. J. INT'L L. 344, 358 (2015); C.L. Lim, The Green Paper from a Constitutional Perspective, 37 H.K. L.J. 741 (2007).

${ }^{152}$ Decision of the Standing Committee of the National People's Congress on Issues Relating to the Methods for Selecting the Chief Executive of the Hong Kong Special Administrative Region and for Forming the Legislative Council of the Hong Kong Special Administrative Region in the Year 2012 and on Issues Relating to Universal Suffrage (promulgated by the Standing Committee of the Tenth National People's Congress at its 31st Meeting, effective December 29, 2007).

${ }^{153}$ Hargreaves, supra note 53, at 538-39.

${ }^{154}$ Decision of the Standing Committee of the National People's Congress, supra note 152.

${ }^{155}$ Hong Kong v. Tsang Yam-Kuen, [2019] H.K.C.F.A.R. 24, FACC 29/2018, at para. 1 (C.F.A. June 26, 2019).

${ }^{156}$ Qu QIANHONG \& Tu YunXin, ON THE Debut of Hong KonG's Impeachment INSTITUTION: THE INTER-RELATIONSHIP between Legislative Power and Executive Power, Research Reports on the Politics of Contemporary China No. 0 241-253 (2015).
} 
members waged numerous attacks against the SAR government and filibustering was frequently weaponized in many later LegCo sessions.

In June 2014, Beijing published the first white paper regarding OCTS, ${ }^{157}$ stating that under the system of the special administrative region, the central government exercises overall jurisdiction (the original Chinese is “全面管治权” which is transliterated as “Quan Mian Guan Zhi Quan”) in the HKSAR. This includes the powers directly exercised by the central government and the powers delegated to the HKSAR by the central government to enable it to exercise a high degree of autonomy in accordance with the law. Some of the most striking language in the 2014 White Paper is "The Hong Kong People Who Govern Hong Kong Should Above All Be Patriotic." By saying so, the Central People's Government has actually set up minimum lines and criteria for Hong Kong's future political figures, including the members of the three governmental branches: Being patriotic. Following the White Paper, in its Decision of August 31, 2014 concerning the electoral framework for LegCo in 2016 and CE in 2017, the NPCSC held the view that "universal suffrage for the selection of the Chief Executive represents a historic progress in Hong Kong's democratic development" and further laid out the details regarding the key principles and procedures which can be summarized as follows: ${ }^{158}$

Principle 1: The Chief Executive of the Hong Kong Special Administrative Region shall be accountable to both the Hong Kong Special Administrative Region and the Central People's Government in accordance with the Hong Kong Basic Law.

Principle 2: The principle that the Chief Executive has to be a person who loves the country and loves Hong Kong must be upheld. This is a basic requirement of the policy of OCTS. The method for selecting the Chief Executive by universal suffrage must provide corresponding institutional safeguards for this purpose.

Principle 3: The principle of gradual and orderly progress in developing a democratic system suits Hong Kong's actual situation and conforms to the majority view in the Hong Kong community.

Procedure 1: A broadly representative nominating committee shall be formed. The provisions for the number of members, composition, and formation method of the nominating committee shall be made in accordance with the number of members, composition and formation method of the Election Committee for the Fourth Chief Executive.

Procedure 2: The nominating committee shall nominate two to three candidates for the office of Chief Executive in accordance with democratic procedures. Each candidate must have the endorsement of more than half of all the members of the nominating committee.

Procedure 3: All eligible electors of the Hong Kong Special Administrative Region have the right to vote in the election of the Chief Executive and elect one of the candidates for the office of Chief Executive in accordance with law.

\footnotetext{
${ }^{157}$ Information Office of the State Council, The People's Republic of China, The Practice of the 'One Country, Two Systems' Policy in the Hong Kong Special Administrative Region, (June 2014), http://english.www.gov.cn/archive/white_paper/2014/08/ 23/content_281474982986578.htm [hereinafter 2014 White Paper].

${ }^{158}$ Decision of the Standing Committee of the National People's Congress on Issues Relating to the Selection of the Chief Executive of the Hong Kong Special Administrative Region by Universal Suffrage and on the Method for Forming the Legislative Council of the Hong Kong Special Administrative Region in the Year 2016 (promulgated by the Standing Committee of the Twelfth National People's Congress at its Tenth Session, effective Aug. 31, 2014).
} 
Procedure 4: The Chief Executive-elect, after being selected through universal suffrage, will have to be appointed by the Central People's Government.

Due to the strict procedures set out in the 2014 NPCSC Decision for Universal Suffrage, from September 28, 2014 on, the world witnessed the "Umbrella Revolution" unfold. Over 200,000 protestors, composed mostly of students, engaged in acts of civil disobedience and occupied the Central District for seventy-nine days. ${ }^{159}$ Scholars have widely used the term "Umbrella Movement" to describe the massive protest, but Benny YT Tai, who was the initial designer of the movement, made clear distinctions between the "Umbrella Movement" and the "Occupy Central Movement." The movement he led shall be the one with "Love and Peace" in the true spirit of civil disobedience, as a later court case confirmed. ${ }^{160}$ The massive movement developed in a way Benny YT Tai himself could not control; violence burst from time to time and police used pepper spray, tear gas, and batons against protesters amid local and international criticism. ${ }^{161}$ The movement formally ended on December 15, 2014 when the SAR government cleared up the last occupied zones in Causeway Bay and the Legislative Council complex. Hundreds of protesters were arrested under Hong Kong's Public Order Ordinance and Criminal Procedure Ordinance. Notably, Benny YT Tai and eight other protesters were found guilty of either committing or inciting public nuisance. District Justice Johnny Chan's opinion in HKSAR v. Tai Yiu Ting and Others stated, "civil disobedience is not a defense to a criminal charge." 162 After the Occupying Central Movement, the constitutional development of Hong Kong went in two directions. On the one hand, localism and pro-independence activism escalated with controversial LegCo Oath-Taking cases; ${ }^{163}$ on the other hand, the Central People's Government introduced the Guangdong-Hong Kong-Macau Greater Bay Area, a national economic project that includes nine mainland cities in the Pearl River Delta and two SARs (Hong Kong and Macau). On July 1, 2017, a framework agreement on the Greater Bay Area project was signed in Hong Kong, ${ }^{164}$ and Beijing formally published an outline development plan in February 2019. ${ }^{165}$ Grand construction projects, such as the Guangzhou-Shenzhen-Hong Kong Express Rail Link and Hong KongZhuha-Macau Bridge, are later credited to the initial success of Greater Bay Area.

\section{Extradition Bill Crisis and Hong Kong National Security Law}

Twenty years after resumption of sovereignty, mutual trust has not yet been fully established between Hong Kong and the mainland. ${ }^{166}$ From early 2018, conflict was generated by the Poon Hiu-Wing murder case, in which a Hong Kong resident named Chan Tong-Kai confessed that he killed his pregnant girlfriend Poon Hiu-Wing during their trip in Taipei. The Hong Kong government was unable to charge him for murder, so the government tried to seize the

\footnotetext{
${ }^{159}$ Kin-Man Chan, Occupying Hong Kong, 21 Sur InT'L J. Hum. RTs. 1 (2015); Jiali Huang, One Country, Two Systems: Hong Kong's Unique Status and the Development and Growth of Arbitration in China, 18 CARDOZO J. CONFLICT RESOL. 423,429 (2017).

${ }^{160}$ Hong Kong v. Tai Yiu Ting, DCCC 480/2017, 36, para. 1 (D.C. Apr. 9, 2019).

${ }^{161}$ Gordon, supra note 151 , at 361-62.

${ }^{162}$ Tai Yiu Ting, DCCC 480/2017 at paras. 261, 273.

${ }^{163}$ Po Jen Yap \& Eric Chan, Legislative Oaths and Judicial Intervention in Hong Kong, 47 H.K. L.J. 1 (2017); Han Zhu \& Albert H. Y. Chen, The Oath-Taking Cases and the NPCSC Interpretation of 2016: Interface of Common Law and Chinese Law, 49 H.K. L.J. 381 (2019).

${ }^{164}$ National Development and Reform Commission, Framework Agreement on Deepening Guangdong-Hong Kong-Macao Cooperation in the Development of the Greater Bay Area, https://www.bayarea.gov.hk/filemanager/en/share/pdf/ Framework_Agreement.pdf.

${ }^{165}$ Outline Development Plan for the Guangdong-Hong Kong-Macao Greater Bay Area, https://www.bayarea.gov.hk/ filemanager/en/share/pdf/Outline_Development_Plan.pdf.

${ }^{166}$ Lin Feng, Constitutionality of the Co-Location Arrangement at the West Kowloon High-Speed Rail Terminus, 47 H.K. L.J. 699, 723 (2017).
} 
opportunity to formulate a radical shift of extradition regimes by proposing a combined legislative amendment to the two ordinances relating to fugitive offenders and mutual legal assistance. The wider scope of coverage and drastic change of the current extradition system catalyzed the biggest political and constitutional controversy in the history of the SAR. In the eyes of the Hong Kong government, effective cooperation in many areas has developed, but not yet in the realm of mutual legal assistance in criminal matters between Hong Kong and other parts of China. ${ }^{167}$ Primarily based on a legal loophole argument, Hong Kong's Security Bureau proposed a bill to amend the Fugitive Offenders Ordinance ("FOO) and the Mutual Legal Assistance in Criminal Matters Ordinance ("MLA") in February 2019. The proposed amendment will allow the SAR government to extradite fugitive offenders to countries or regions without extradition agreements with Hong Kong, including Taiwan, Macau, and mainland China.

It is obvious that adopting and implementing the FOO and MLA will significantly alter the current extradition regimes. The Hong Kong Bar Association released its position paper and statements on March 4, 2019; April 2, 2019; June 6, 2019; and June 21, 2019, arguing that it would "fundamentally imperil the operation of the rule of law in Hong Kong." 168 Scholars held that the Extradition Bill led to the most serious crisis of governance since the establishment of the SAR. ${ }^{169}$ From March 2019 on, thousands of protesters marched on the streets opposing the proposed extradition bill. Many of the pro-democracy legislative members, legal sectors, business communities, students, civil societies, and human rights groups participated in a series of massive protests that lasted several months. The massive protests were reported by domestic and international media to have reached their peak in June 2019, but escalation of tensions continued after Carrie Lam suspended and finally withdrew the controversial bill. Peaceful protests finally turned into a series of incidents of violence, protesters masking themselves on the streets, and police officers using pepper spray and rubber bullets to quell demonstrations. To tackle the dire situation, on October 4, 2019, the Chief Executive-in-Council, in the exercise of the power under section 2 of the Emergency Regulations Ordinance (the "ERO"), announced the enactment of the Prohibition on Face Covering Regulation (the "PFCR"). ${ }^{170}$ The PFCR was a controversial bill that banned people from covering up their faces in public meetings, processions regulated under the Public Order Ordinance, and unlawful and unauthorized assemblies, such as riots. ${ }^{171}$ Twenty-four LegCo members swiftly filed an urgent application for interim relief to prevent the PFCR from taking effect, but that claim was declined by the High Court because it could not step in at this stage by suspending the PFCR in the interim. ${ }^{172}$ The Court of First Instance, on November 18, 2019, handed down a decision declaring that the ERO was partly incompatible with the Basic Law. ${ }^{173}$ After the decision, the government appealed, and, on April 9, 2020, the Court of Appeal upheld the constitutionality of the ERO and ruled that the PFCR was legal. ${ }^{174}$ Hong Kong gradually became a "city of protest" and the situation in Hong Kong has drawn international attention. The European Parliament passed a resolution on July 18, 2019 regarding the situation in Hong Kong, calling on the HKSAR government to withdraw the bill. ${ }^{175}$ The United States Congress passed the Hong Kong Human Rights and Democracy Act of 2019 ("HKHRDA") in

\footnotetext{
${ }^{167}$ Hong Kong v. Hon Ming Kong, [2014] 2 H.K.L.R.D. 710, para. 591 (C.A. Mar. 28, 2014).

${ }^{168}$ Press Release, Hong Kong Bar Association, On the Fugitive Offenders and Mutual Legal Assistance in Criminal Matters Legislation (Amendment) Bill 2019 (June 21, 2019) (on file with author).

${ }^{169}$ Albert H. Y. Chen, A Perfect Storm: Hong Kong-Mainland Rendition of Fugitive Offenders, 49 H.K. L. J. 419 (2019).

${ }^{170}$ Kwok Wing Hang v. Chief Executive in Council, CACV 542/2019, para. 3 (C.A. April 9, 2020).

171 Anti-Mask Law Gazetted, NEw.Gov.HK (Oct. 4, 2019), https://www.news.gov.hk/eng/2019/10/20191004/ 20191004_181429_379.html.

${ }^{172}$ Kwok Wing Hang v. Chief Exec. in Council, HCAL 2945/2019 paras. 2, 17, 18 (C.A. Oct. 8, 2019).

${ }^{173}$ Leung Kwok Hung v. Secretary for Justice, HCAL 2949/2019 para. 193 (C.A. Nov. 18, 2019).

${ }^{174}$ Kwok Wing Hang v. Chief Exec. in Council, CACV 542/2019 para. 355 (C.A. Apr. 9, 2020).

${ }^{175}$ Resolution on the Situation in Hong Kong, EUR. PARL. DOC. (2019/2732(RSP)).
} 
late November of 2019 with strong concerns for Hong Kong's unique status under OCTS. ${ }^{176}$ Amid the COVID-19 global pandemic, China's third session of the thirteenth NPC passed the Decision to Establish and Improve a Legal Framework and Enforcement Mechanism for Safeguarding National Security in Hong Kong on May 28, 2020. One month later, the Standing Committee of the NPC passed the Hong Kong National Security Law and listed the legislation in Annex III to the Hong Kong Basic Law. The new law was swiftly gazetted for promulgation in Hong Kong and took effect on June 30, 2020. The enactment of the Hong Kong National Security Law deeply worried the United States, and the Trump administration signed the Hong Kong Autonomy Act into law on July 14, 2020.

There are several political and legal arguments that the Hong Kong government can utilize to prevent the city from becoming a "Safe Harbor for Criminals," in essence plugging legal loopholes and accelerating the effective handle of surrender requests from other jurisdictions. It is foreseeable, however, that it will bring serious challenges for Hong Kong's current legal system, and there are widespread concerns for the human rights record of the mainland system. The legal loophole arguments were poorly put forward because the extradition issues were previously discussed when the 1984 Joint Declaration was signed. What's more, the permissive terms of Article $95^{177}$ of the Basic Law plainly do not impose a duty to put in place a scheme for mutual legal assistance in criminal matters between the mainland and other parts of China. ${ }^{178}$ The unprecedented COVID2019 pandemic quieted most demonstrations in Hong Kong due to the adoption of various social distancing measures. The Hong Kong National Security Law seemed to have ended the Extradition Bill crisis, as we can see a new legal order that favors mainland China is emerging. ${ }^{179}$ Under Article 44 of the newly promulgated law, the CE has the power to designate judges to hear cases concerning offenses endangering national security. It is reasonable to predict that national security cases will become highly controversial, thereby creating more constitutional crises in the foreseeable future.

\section{Searching for the True Meaning of "Unchanged for 50 Years"}

The conception of OCTS anticipates at least three accomplishments; namely, the peaceful resolution of historically international territorial disputes; ultimate national unification; and maintaining the stability and prosperity of SARs. It is indeed a Chinese centenary project that tests the collective wisdom of generations of Chinese people. In the absence of a clear timetable, Mao Zedong even proclaimed that the solution to the Taiwan problem could "wait 100 years, even a thousand." ${ }^{80}$ As a constitutional experiment as grand as any other, ${ }^{181}$ OCTS has only been implemented for a short period of two decades and any attempts to draw a definitive conclusion have to be tested by history itself. For constitutional lawyers attempting to give legal bite to the exact meaning of the legal provisions enshrined in the Basic Law, OCTS inevitably affects and determines the interpretive process, initiating political and legal puzzles and generating a relativistic understanding of the boundary of the "two systems" set out in the text of the Basic Law. This

\footnotetext{
${ }^{176}$ See Jean Galbraith, Congress Signals Concern About Human Rights Abuses in China, 114 AM. J. INT'L L. 304 (2020); STAFF OF U.S.-China ECONOMic AND SeCurity Review Commission, 2019 Report to Congress: Hong Kong 481 (2019). See also Hong Kong Human Rights and Democracy Act of 2019, H.R. 3289, 116th Cong. (2019), https://www.congress.gov/bill/116thcongress/house-bill/3289.

${ }^{177}$ Article 95 states that the Hong Kong Special Administrative Region may, through consultations and in accordance with law, maintain juridical relations with the judicial organs of other parts of the country, and they may render assistance to each other.

${ }^{178}$ Hong Kong v. Hon Ming Kong, [2014] 17 H.K.C.F.A.R. 727, para. 7 (C.F.A.).

${ }^{179}$ See generally China's National Security: Endangering Hong Kong's Rule of Law? (Cora Chan \& Fiona de Londras eds., 2020).

${ }^{180}$ Lucian W. Pye, The International Position of Hong Kong, 1983 CHINA Q. 456, 464 (1983).

${ }^{181}$ See Abrams v. United States, 250 U.S. 616, 630 (1919) (Holmes, J., dissenting).
} 
boundary of the two systems in one country, which distinguishes itself from that of other interstate relationships purely under public international law, gives both Beijing and Hong Kong the limits and latitudes to implement the Basic Law over time depending upon the changing circumstances in the spirit of the law, rather than requiring them to stick to a single static benchmark. The aforementioned two-decade practice of OCTS over Hong Kong proves to be a remarkable and unexpected journey. All the constitutional players, including the people of Hong Kong, have shaped the trajectory of OCTS. Nevertheless, Beijing has insisted that OCTS must be understood within the constitutional framework of China's sovereignty which requires faithful implementation of the Basic Law. "Unchanged for 50 years" provides an understanding of the constitutional direction that the two systems should co-exist in and provides an indication as to the future of China's national unification project. "Unchanged for 50 years" is a constitutional clause enshrined in Article 5 of the Basic Law which reads: "The socialist system and policies shall not be practiced in the Hong Kong Special Administrative Region, and the previous capitalist system and way of life shall remain unchanged for 50 years."

Before any substantive inquiry of Article 5 of the Basic Law, it is imperative for any cautious readers to carefully examine the historical and philosophical background of the entire Basic Law and then to question the mentality of our collective imagination on the temporality of OCTS. First, for anyone who would like to decipher the time-code of the Basic Law, the language of "unchanged for 50 years" seen in black and white was clearly crystallized in both the 1984 Joint Declaration and the 1990 Basic Law. As for the nature of the phrase, being in the main body of the two instruments with normative implications, the language itself is the evidence for the existence of the law, though interpretation on it may vary from time to time and from person to person. Second, for those aiming to provide a calculable standard over the language itself, the conception of OCTS purports to survive the national unification project unless that mission fails at the end of the day. Third, for international commentators or observers hoping to test the validity of "unchanged for 50 years" for Hong Kong, the connotations of OCTS deserves lengthy global governance debates.

During the early 1990s, scholars noted that several key questions remained unresolved by the 1984 Joint Declaration: (1) The definition of "high degree of autonomy"; (2) the extent to which Hong Kong may enjoy the right to final adjudication to interpret the Basic Law and the powers of the NPC Standing Committee to annul laws that in their opinion do not comply with the Basic Law; (3) the meaning of "elections or consultations to be held locally," "to choose the Chief Executive," and the definition of the phrase that "the legislature shall be constituted by elections"; and (4) the extent to which Chinese would be used in the law. ${ }^{182}$ Largely reflected in the drafting process of the Basic Law, the unresolved Sino-British questions continued to trap the drafters, sowing the seeds for their stumbling journey when the constitutional mechanism functions to its full power. As time goes on, one of the most striking issues concealed for the constitutional machinery of OCTS is its temporality. Treaty parties and Basic Law drafters may well seal the issue for reasons of political expediency and pragmatics at the time, but question on what "unchanged for 50 years" really means ultimately will become imminent one day. I therefore suggest that there are at least three dimensions, along with the rise of China, which is a perspective from the north of the Shenzhen River, that hold the most relevance for our contemporary debates on the constitutional fate of Hong Kong. Amid the enormous doubts and criticism of China's Hong Kong policies, it is necessary to distinguish two constitutional perspectives. One perspective is to interpret the Basic Law in a way that favors "one country," and the other perspective is understand the Basic Law in a fashion that favors "two systems." Although the danger of blurring the two constitutional perspectives at this time is enormous, one may well judge and cast doubts on my analysis on whether I can achieve that goal by only arguing for the rule of law.

${ }^{182} \mathrm{Neoh}$, supra note 5 , at 328. 


\section{1. "Unchanged for 50 years" as International Promise}

The issue of Hong Kong, in many ways, has been described as an enigma. ${ }^{183}$ In order to decipher the time-code of the Basic Law, it is of great value for one to bear in mind that the Basic Law adopts many of the same principles contained in the 1984 Joint Declaration. ${ }^{184}$ Albert Chen considers the identical wordings of the two documents as a "Duplication Phenomenon" and the Joint Declaration is highly relevant to understanding the legislative intent of the Basic Law. ${ }^{185}$ Furthermore, the international dimension of the Basic Law is recognized in several landmark cases by the Hong Kong judiciary, such as HKSAR v. Ma Wai Kwan David ${ }^{186}$ and Ng Ka Ling v. Director of Immigration. ${ }^{187}$ The Basic Law is an entrenched constitutional instrument used to implement the unique principle of OCTS. ${ }^{188}$ Thus, a careful reading of the Joint Declaration is not only useful but is also necessary for a constitutional survey of the key provisions under the Basic Law. The Joint Declaration, as a bilateral treaty between the UK and China registered at the United Nations on May 27, 1985, consists of a brief preamble, eight paragraphs, and three annexes respectfully dealing with China's basic policies on Hong Kong, the Joint Liaison Group, and land lease issues. The term "unchanged for 50" appears twice in the treaty, once in Paragraph 3(12) of the main body and another in Section 1 of Annex I. In the main body of the treaty text, Paragraph 3 directly addresses the twelve basic policies of the PRC regarding Hong Kong, ranging from the governance structure of the SAR to the status of a free port and a separate customs territory. Those twelve basic policies are further elaborated in Annex I of the Treaty, with 14 sections that are much more detailed. Paragraph 3(12) of the Joint Declaration reads as the following:

The above-stated basic policies of the People's Republic of China regarding Hong Kong and the elaboration of them in Annex I to this Joint Declaration will be stipulated, in a Basic Law of the Hong Kong Special Administrative Region of the People's Republic of China, by the National People's Congress of the People's Republic of China, and they will remain unchanged for 50 years.

Section 1 of Annex I further elaborates the general language used in paragraph 3(12) of the treaty by providing that "after the establishment of the Hong Kong Special Administrative Region the socialist system and socialist policies shall not be practiced in the Hong Kong Special Administrative Region and that Hong Kong's previous capitalist system and life-style shall remain unchanged for 50 years."

Both Paragraph 3(12) and Section 1 of Annex I of the Joint Declaration explicitly incorporate "unchanged for 50 years" as the key for maintaining OCTS. Although immediately before Paragraph 3(12) there are eleven sub-paragraphs guaranteeing that the social and economic systems in Hong Kong will remain unchanged, paragraph 3(12) affirms that the above-stated eleven basic policies will remain unchanged for 50 years. It is in this sense that the "unchanged for 50 years" clause can be deemed "the basic policy of all basic policies." Section 1 of Annex I of the Joint Declaration is of equal importance for a more precise understanding of "unchanged for 50 years" because it furthers Paragraph 3(12) by adding a negative list - the socialist system and socialist policies shall not be practiced in the SAR — and a positive list Hong Kong's previous capitalist system and lifestyle shall remain. This even reminds careful readers of the first two commandments (mitzvah) on Mount Sinai. Without Section 1 of Annex I, Paragraph 3(12) would be in peril or at least fragile. Besides those two provisions, Sections 2 and 3 of Annex III also explicitly mention June 30, 2047 as a clear date regarding new leases of land by the British Hong Kong government. All those provisions lead us to the question of 2047 and to how to understand "unchanged for 50 years."

\footnotetext{
${ }^{183} I d$. at 309.

${ }^{184}$ David Carter, Hong Kong: Is Democracy in Its Future, 3 J. INT'L L. \& PraC. 551, 553 (1994).

${ }^{185}$ Albert H. Y. Chen, "The Foreign Domestic Helpers Case": The Relevance of the NPCSC Interpretation of 1999 and the Preparatory Committee Opinion of 1996, 41 H.K. L.J. 621, 629 (2012).

${ }^{186} \mathrm{Ma}$ Wai Kwan David Case at para. 13.

${ }^{187} \mathrm{Ng}$ Ka Ling Case at para. 74.

${ }^{188} I d$. at para. 73 .
} 


\section{Consensus-Building Approach}

The first approach regarding the international dimension of "unchanged for 50 years" is the one which seeks to achieve an international consensus for the settlement of the final status for the former British colony. It is an approach that distinguishes itself by treaty-making rather than by treaty interpretation. Treaty-making reflects the will of the parties to be bound by their terms. ${ }^{189}$ It is essentially a consensus building process in which two concurring wills meet. Treaties, however, are a result of a complex process of collective bargaining between states with conflicting interests. ${ }^{190}$ In this process, it is hoped that state parties spare their best efforts to the maximum of their ability to achieve a common understanding of key issues with conflicting interests. This often leads to sacrifice or to the compromise of certain state interests. Applying the consensus-building approach to complex treaty-making processes has advantages in fostering constructive dialogue while allowing disagreement at its fringes. The more difficult issue left for those other than the drafters would be searching for evidence of the consent made by state parties; some are explicit, and some are not. Draft records attest to the explicit consensus reached by state parties, while tacit consent between state parties is measured by the parties' past behaviors. ${ }^{191}$ Consensus can be utilized as a method of domestic lawmaking as well as international treaty-making. ${ }^{192}$ Although the concept of consensus is difficult to specify, ${ }^{193}$ at least one may distinguish core consensus from peripheral consensus. In an international setting, core consensus is best evidenced by some of the basic principles in treaty provisions, and peripheral consensus tends to be vague, leaving space for later developments.

The 1984 Joint Declaration was negotiated between two representative governments. According to Article 89(9) of the Chinese Constitution, the power to conclude treaties and agreements with foreign states is vested in the State Council. ${ }^{194}$ In Commonwealth states, the treaty-making power rests at the common law with the executive branch of the government, despite the fact that a parliament is the ultimate law-making authority in a Westminster-style democracy. ${ }^{195}$ At the time of bargaining, consensus-building was essential when both the PRC and Britain tried to reach a core consensus by virtue of their practical concessions on some of the key points. From September 1982 to September 1984, there were twenty-two rounds of negotiations by the two sides, but it was not until the fifth and sixth round that Britain renounced its claims based on the 1842 Treaty of Nanking. In March 1983, the British Government finally recognized that China had sovereignty over Hong Kong. In a letter to Chinese Premier Zhao Ziyang, Thatcher stated that:

$[\mathrm{P}]$ rovided that an agreement can be reached between the two sides on administrative arrangements for Hong Kong to guarantee the future prosperity and stability of Hong Kong and is acceptable to the British Parliament and to the people of Hong Kong as well as to the Chinese Government, I would be prepared to recommend to the Parliament that sovereignty over the entire Hong Kong would be returned to China. ${ }^{196}$

\footnotetext{
${ }^{189}$ OpPenheim's InTERnAtional LAW 1208 (Robert Jennings \& Arthur Watts eds., 9th ed. 1992).

${ }^{190}$ Shai Dothan, The Three Traditional Approaches to Treaty Interpretation: A Current Application to the European Court of Human Rights, 42 FordHAM INT'L L.J. 765, 782 (2019).

${ }^{191}$ Martti Koskenniemi, From Apology to Utopia: the Structure of International Legal Argument 327 (2006).

${ }^{192}$ Mary E. Footer, Role of Consensus in GATT/WTO Decision-Making, 17 NW. J. INT'L L. \& Bus. 653,657 (1997).

${ }^{193}$ Joseph Landau, New Majoritarian Constitutionalism, 103 IowA L. REV. 1033, 1043 (2018).

${ }^{194}$ Bjorn Ahl, The Delineation of Treaty-Making Powers Between the Central Government of the People's Republic of China and the Special Administrative Region of Hong Kong, 31 Chinese (TAIWAN) Y.B. InT'L L. \& AfF. 116, 118 (2013).

${ }^{195}$ Joanna Harrington, Redressing the Democratic Deficit in Treaty Law Making: (Re-) Establishing a Role for Parliament, 50 MCGILl L.J. 465, 468 (2005).

196 Sino-British Relations and the Sino-British Joint Declaration, in THE BASIC LAW AND HONG KONG: THE 15 $5^{\text {th }}$ ANNIVERSARY OF REUNIFICATION WITH THE MOTHERLAND (2012), https://www.basiclaw.gov.hk/en/publications/book/ 15anniversary_reunification_ch1_2.pdf.
} 
The core consensus that the delegates from both sides reached from September 1982 to March 1983 was that China would resume sovereignty over Hong Kong in its entirety on July 1, 1997. From the seventh round, the gravity of the negotiation shifted to the twelve Basic Policies proposed by the Chinese government. When the draft proposal of Paragraph 3 of the 1984 Joint Declaration was on the table, there were only broad and vague political guidelines laid out by Thatcher and Deng. Even the two political figures could not have a clear detailed prospect with what would happen in the far future, say, 100 years later. Later revealed records show that it was China who proposed that 12 Basic Policies would remain "unchanged for 50 years." After lengthy negotiations, Britain finally agreed with China on a term of "unchanged for 50 years," and this consensus is reflected in the final version of the Joint Declaration and the much later Basic Law.

\section{Treaty Interpretation Approach}

The second approach is an interpretative one which is well-established as both treaty law ${ }^{197}$ and customary international law. ${ }^{198}$ As laid out by the Vienna Convention on the Law of Treaties ("VCLT") and the jurisprudence surrounding it, traditional rules of treaty interpretation include textual, subjective, and teleological approaches through jurisprudential techniques like the principles of effectiveness, integration, and contemporaneity, which may vary sharply at some points. ${ }^{199}$ Article 31(1) of the VCLT emphasizes a textual approach by providing that "a treaty shall be interpreted in good faith in accordance with the ordinary meaning to be given to the terms of the treaty in their context and in the light of its object and purpose." ${ }^{200}$ In highly complex cases, the doctrine of "ordinary meaning" will compel the tribunal to make careful inquiry into the precise object and purpose of a treaty, and the proponent of a special meaning has the burden of proof. $^{201}$ It is often the case that disagreeing parties would have constant competitions for acceptance of their own understanding of the ordinary meaning of treaty terms. Both subjective and objective positions may be utilized by state parties as strategies in such situations. As Martti Koskenniemi argues, the intent of "ordinary meaning" can be known only in its manifestations. ${ }^{202}$ It is further suggested by the principle of integration that obscurities in treaty texts may be cleared up from the immediate context or from subsequently occurring texts. ${ }^{203}$ Article 32 of the VCLT recognizes preparatory work of the treaty and circumstances of its conclusion as supplementary means of interpretation. Travaux préparatoires, as the International Law Commission in its commentary points out, may throw light on the expression of agreement in the text. ${ }^{204}$

When the terms of a treaty are stated explicitly, the treaty interpretation approach usually incorporates language such as "unchanged for 50 years," as its wording shows in the first place. When this is done inexplicitly, other interpretation methods such as the teleological approach may be deployed. A treaty interpretation approach to "unchanged for 50 years" certainly suggests that OCTS must be preserved unchanged for 50 years. A normal understanding of " 50 years" under the Joint Declaration would be a period of time of 50 years, starting from July 1, 1997 and ending on June 30,2047 . In other words, the ordinary meaning of " 50 years" should be construed as 50 times 365 , that is, 18,250 days. This approach seems to leave very little space for any alternative interpretation of " 50 years" under the Joint Declaration. Even by referring to the principle of

\footnotetext{
${ }^{197}$ VCLT at arts. $31-33$

${ }^{198}$ Arbitral Award of July 31, 1989 (Guinea-Bissau v. Senegal), 1991 ICJ Reports 53, 70; Pulau Ligitan/Sipadan, 2002 ICJ Reports 625, 645; Avena and Other Mexican Nationals (Mexico v. US), 2004 ICJ Reports 12, 48; Genocide (Bosnia and Herzegovina v. Serbia and Montenegro), 2007 ICJ Reports 43, 109-10.

${ }^{199}$ Dothan, supra note 190 , at 766.

${ }^{200} \mathrm{VCLT}$ at art. 31(1).

${ }^{201}$ James Crawford, Brownlie's Principles of Public International Law 382 (8th ed. 2012).

${ }^{202}$ KosKenNIEMI, supra note 191 , at 337.

${ }^{203} \mathrm{VCLT}$ at art. 31(2).

${ }^{204}$ YeARboOK OF THE INTERNATIONAL LAW COMMISSION 219-20 (1996).
} 
contemporaneity, the language of a treaty must be interpreted in light of the contemporaneous meaning of the term; ${ }^{205}$ our understanding of " 50 years" in 1984 would remain the same as now. In the course of contemporary debates on the meaning of "unchanged for 50 years," there are two ways of reading of that language. One is to read it as a "ceiling" and another is to read it as a "floor." The "ceiling" reading suggests that OCTS only lasts for 50 years without extension, while the "floor" reading gives possibilities for OCTS to be continued beyond 2047. I am inclined to argue that a "floor" reading is more appropriate to grasp the telos of the language. Why did the negotiators consent on "unchanged for 50 years," as opposed to "30 years" or "70 years?" To what purpose are the two parties bound? To what purpose are those obligations committed to writing? It is a proposition too plain to be contested, ${ }^{206}$ that the general welfare of the Hong Kong people was only given the chance to be guaranteed for 50 years. Losing sight of the further consideration of this subject may result in fatal consequences.

\section{Critiques}

The importance of international obligations in constitutional interpretation and adjudication in domestic courts has been recognized in the past, such as in the South African Constitutional Court, which is widely deemed to be progressive. ${ }^{207}$ By the same token, Article 39 of the Basic Law also provides legal channels for constitutional interpretation with reference to international treaties and conventions. Understanding "unchanged for 50 years" by looking at international agreements is based on a firm belief that the legal nexus of the Joint Declaration and Basic Law shall be observed. However, this could be challenged from various political and legal angles. First, recent years have seen the emerging views both by HKSAR and the Central People's Government that the international dimension of the Basic Law is of less and less relevance for the constitutional machinery of Hong Kong. Raymond Tam, a senior official in HKSAR, noted that many provisions of the Joint Declaration consist of unilateral statements by the Chinese government rather than joint statements with Britain. ${ }^{208}$ Beijing tends to redefine the Joint Declaration as only being applicable to the period between its signing and China's resumption of sovereignty on July $1,1997 .{ }^{209}$ Second, critics argue that the Joint Declaration is a future policy and its ambiguities are the stuff of diplomatic double speak, not law. ${ }^{210}$ What matters most is the changing social practice: The Joint Declaration would not entrench the Basic Law if the treaty is to be enforced against China, and it does prevent the Basic Law from being repealed or modified though simple legislation. ${ }^{211}$

Attempts to defy the validity of the Joint Declaration have been rising, especially during the postOccupy years. Some attempts are political and some are legal. Beijing has repeatedly stated that the goals of "high degree of autonomy" and "Hong Kong People Running Hong Kong" have been successfully implemented under the Basic Law. Beijing calls all foreign governments not to interfere with its domestic affairs, which are essentially under its sovereign jurisdiction. ${ }^{212}$ It seems that the Joint Declaration is merely of historical significance for Beijing. This position is fiercely opposed by the U.K. and U.S. because the Joint Declaration is indeed a UN-registered binding treaty.

Arguments against treating "unchanged for 50 years" as an international promise may come from those who insist on purely constitutional interpretation. Some constitutional scholars put

\footnotetext{
${ }^{205}$ CRAWFORD, supra note 201, at 382.

${ }^{206}$ Marbury v. Madison, 5 U.S. (1 Cranch) 137, 177 (1803).

${ }^{207}$ Azanian Peoples Org. v. President of the Republic of South Africa 1996 (4) SA 671 (CC) at para. 26 (S. Afr.); S v. Makwanyane 1995 (3) SA 391 (CC) at para. 35 (S. Afr.); Glenister v. President of the Republic of South Africa 2011 (3) SA 347 (CC) at paras. 191-92, 195; Edwin Cameron, Constitutionalism, Rights, and International Law: The Glenister Decision, 23 Duke J. Comp. \& INT'L L. 389, 405-06 (2013).

${ }^{208}$ GitTINGS, supra note 8 , at 40 .

${ }^{209} I d$. at 39.

${ }^{210}$ Fiss, supra note 113 , at 498.

${ }^{211} I d$.

${ }^{212}$ See 2014 White Paper at 157.
} 
forward legal arguments that the Joint Declaration could only be used as auxiliary material, not necessarily as a constitutional basis. A closer look at the practice of the Hong Kong judiciary, both in HKSAR v. Ma Wai Kwan David and $\mathrm{Ng} \mathrm{Ka} \mathrm{Ling} \mathrm{v.} \mathrm{Director} \mathrm{of} \mathrm{Immigration,} \mathrm{only} \mathrm{refer} \mathrm{to} \mathrm{the}$ Joint Declaration as a "useful aid," not as a "fundamental basis" for interpreting the "context" and "purpose" of the Basic Law. ${ }^{213}$ The Joint Declaration is only treated as "extrinsic material" rather than "internal material" for the purpose of Basic Law interpretation. Admittedly, opinio juris and state practice under the law of nations may provide some desirable inspirations for understanding the Basic Law, but treaty interpretation seems to be not fully convinced, by and large, as a constitutional foundation upon which China must adhere to after 2047.

\section{II. "Unchanged for 50 Years" as Political Commitment}

HKSAR is established under the auspices of Article 31 of the Constitution of the PRC. The Basic Law is not only a brainchild of an international treaty, but also a national law of the PRC and the constitution of the HKSAR."214 Judging the Basic Law as a Chinese national law that binds both Beijing and Hong Kong is in line with its political purposes. Constitutional law is both a mechanism of political commitment and is itself a political commitment. ${ }^{215}$ In this sense, the Basic Law can also be judged as a political commitment, and it prevents the two systems in the mainland and in Hong Kong from mixing with each other on some of the fundamental issues. Concerns over "unchanged for 50 years" rest upon the fundamental question of whether the political commitment by China can be sustained or not. Given that the Chinese language is rich with pithy yet evocative sayings, ${ }^{216}$ "unchanged for 50 years" is easily remembered but is not crystal clear. In the political process of implementing OCTS, a reasonable observer would naturally ask questions such as: What does "50 years" exactly mean? What is the correct understanding of "unchanged?" Is "50 years" an exact quantity or is it inexact? ${ }^{217}$ Shall we simply calculate the dates with the Chinese or Gregorian calendars to fix the meaning of "50 years?" To answer those questions is not an easy task. It is far more complicated than the linguistic ambiguities themselves. When the Joint Declaration was to be signed by the two governments, Margaret Thatcher had conversations with Deng Xiaoping on why it should be "50 years." The same question was posed by one of Deng's Japanese friends. Historical diplomatic records provided very vague responses to the question, but it's useful to look at Deng's remarks on December 19, 1984:

That we say ' 50 years,' is not casually, is not driven by emotional impulse, it is based on the necessity of China's realities and developments. Meanwhile, at the end of this century and to the first 50 years for the next century, we need a stable Taiwan. Taiwan is part of China, China can adopt two systems under one country, this is the very idea when our country made the national policy. If this point is understood, our basic viewpoints are known, if the basis on which we proposed this slogan, made this polity is known, [you] will know that we will not change. I further said to the Japanese friend, if the opening-up policy remains unchanged for the first 50 years during the next century, then after that 50 years, we will have more frequent economic exchanges internationally and become more inter-dependent, inseparable, the opening-up policy will remain unchanged even further. ${ }^{218}$

\footnotetext{
${ }^{213} \mathrm{Ma}$ Wai Kwan David Case at para. 74.

${ }^{214} I d$. at para. 42.

${ }^{215}$ Daryl J. Levinson, Parchment and Politics: The Positive Puzzle of Constitutional Commitment, 124 HaRv. L. REv. 657, 697 (2011).

${ }^{216}$ Lee, supra note 122 , at 627.

${ }^{217}$ Tian Lei, Three Dimensions of Remaining Unchanged for 50 Years on the Concept of Time in HKSAR Basic Law, 30 Peking U. L.J. 782, 784 (2018).

${ }^{218}$ Deng Xiaoping, China Is Promise-Keeping, in Selected Works of Deng XIAOPING 102-103 (1993). [邓小平: 《中国是 信守承诺的》，载《邓小平文选》, 人民出版社1993 年版, 第102-103 页。].
} 
If Deng were to be understood exactly by what he said in 1984, he would not have been confronted with the same question over "unchanged for 50 years" in 1988. It was four years after the conclusion of the Joint Declaration that Deng repeated his 1984 remarks, adding that "unchanged for 50 years" over Hong Kong was a sacred political promise. ${ }^{219}$ On June 3, 1988, Deng clarified this as the following:

As for the Hong Kong policy, we have made promise of 'unchanged for 50 years' after 1997, this promise is sacred. Why unchanged for 50 years? There is a basis, not only just for setting the minds of Hong Kong people at rest, but also for the consideration of the relationship between the sustaining prosperity of Hong Kong and China's strategy of developments. It takes time for China's development strategy, beside the 12 years for this century, for the next 50 years during the next century, how could we change our policy for the 50 years? Now we have one Hong Kong, we will build several "Hong Kong" in the mainland, that is to say, in order to realize our development strategy, we need more opening-up. Since it is so, how can we change our Hong Kong policy? In fact, 50 years is a vivid saying, after 50 years, the policy will not be changed. For the first 50 years, it can not be changed, for the time after 50 years, there is no need for changes. So, this is not speaking at random. ${ }^{220}$

Comparing Deng's remarks in 1984 and 1988, they basically show the consistency of China's Hong Kong policy, but there are some very subtle nuances. First, the 1988 remarks set out July 1, 1997 as the starting date for implementing the Hong Kong policy. This has cleaned up the doubts surrounding when the "unchanged for 50 years" policy should be implemented Second, China's centennial strategy of developments is utilized as the justification for maintaining Hong Kong's polity "unchanged for 50 years." Third, the question of China's Hong Kong policy after 50 years is addressed directly in the affirmative. That is to say, OCTS in Hong Kong is designed not only for the period between 1997 and 2047-it goes well beyond 2047.

As Rubenfeld pointed out, "speech speaks in modern political theory." ${ }^{221}$ Deng's remarks can be analyzed in the context of modern political theory as a political commitment. Like Ulysses who tied himself to the mast with rope, preparing himself for the irrational passions he expected to encounter in the future, ${ }^{22}$ for a people to exist and govern themselves freely, they must make durable, generation-spanning commitments. ${ }^{223}$ There are several political implications for our contemporary understanding of "unchanged for 50 years:" (1) It is a pre-commitment made by the founders of the Basic Law which has bearings for our generations to be bound by it; (2) it is a political commitment for which only time will test its truth or falsity; (3) the political commitment is constitutionally enforceable by various institutions and mechanisms; (4) it is a political commitment that is a self-conscious effort to make policies or institutional arrangements difficult to change; ${ }^{224}$ and (5) the political commitment is closely related to the legitimacy of the current constitutional arrangements in Hong Kong, and any radical changes to the political commitment would endanger the legitimacy of the Basic Law. To answer the question of what will happen after 2047 in Hong Kong, one has to understand the whole context of the political commitment. Deng, as well as many other later Chinese political leaders, is aware of this-it takes time for China's development strategy to be realized. As long as China's centennial blueprint has not come into fruition, China and the CCP are bound by their political commitments. Doubts concerning the regime's willingness to abide by those political commitments are, to a large extent,

\footnotetext{
${ }^{219} I d$. at 267.

${ }^{220} I d$.

${ }^{221}$ Jed Rubenfeld, Freedom and Time: A Theory of Constitutional Self-Government 46 (2001).

${ }^{222}$ Michael J. Gerhardt, The End of Theory, 96 Nw. U. L. Rev. 283, 294 (2001) (reviewing Jed RubenfeLD, FrEEDOM AND Time: A Theory of Constitutional Self-Government (2001)).

${ }^{223}$ Christopher L. Eisgruber, Dimensions of Democracy, 71 FORDHAM L. REV. 1723, 1725 (2003).

${ }^{224}$ Levinson, supra note 215 , at 672 .
} 
skepticism toward CCP's commitments to the rule of law and democratic governance. I would argue that those political commitments bind the CCP and the Chinese government based on both idealist and pragmatist approaches.

\section{Idealist Approach}

The idealist approach to any durable political commitment assumes that decision-makers commit themselves to a promise in certain circumstances. This approach distinguishes itself from a pragmatic approach in the sense that principles triumph expediencies. The idealist approach tends to treat "unchanged for 50 years" as a pre-commitment which binds China itself, much as Ulysses bound himself to his prior commitment not to heed the sirens' call. ${ }^{225}$ The idealist approach also makes a fundamental distinction between the ideals themselves and the practices which may survive or fail the ideals. It is suggested that impediments or challenges for OCTS are matters of practical difficulties, not matters of inherent flaws of the ideals themselves. The ideal of OCTS accommodates two major, ideologically different systems; namely, the socialist system and the capitalist system. The godfather of communism, Karl Marx did not develop such a political idea. As a Chinese invention, OCTS relies upon the presumption that socialist and capitalist systems shall coexist for a considerably long period of time. Chinese politicians believe that the peaceful coexistence of the two systems can be achieved on the international level as well as on the domestic level. In a transnational setting, peaceful coexistence of the two systems is governed by global legal order, and China can maintain its system by pleading the traditional Westphalian notion of sovereignty. However, when dealing with the coexistence of the two systems in a domestic scenario, no precedents are available. Then the question becomes how to make real sense of OCTS, and furthermore, how to reconcile the enormous differences between the two legal systems within one sovereign framework. Is it a concession of one system to another? Are the two systems doomed to conflict? Is it a paradoxical combination of Leninist authoritarianism and liberal democracy? ${ }^{226}$ In answering these questions, conventional wisdom based on either unitarianism or federalism will fall short. I argue that OCTS should be interpreted through an idealistic approach.

OCTS is a gigantic constitution designed in the 1980s for one-fifth of the world's humanity. When it comes to national unification, the subject speaks to its own importance for billions of Chinese people. It seems to be timely for the Chinese people to decide the important question of whether or not they are capable of establishing good government from reflection and choice. ${ }^{227}$ When the constitutional time for Hong Kong comes, the destiny of the former British colony fundamentally changed. It is important to note that the Basic Law is a Grundnorm (or basic norm) change ${ }^{228}$ from a Kelsenian perspective. In the eyes of the founding fathers of OCTS, "accident and force" were not absolutely ruled out if circumstances fundamentally changed, but the constitutional design of Hong Kong was based on a noble ideal that the two systems may and must coexist peacefully. It is emphatically stated in the Basic Law that the Hong Kong capitalist system will remain "unchanged for 50 years." By doing so, the drafters actually made a political commitment for the people of Hong Kong and also for the people of mainland China. It shall be pointed out that the political commitment is binding upon China because it promised that the socialist system shall not be practiced in Hong Kong. Then the question becomes how to guarantee the autonomous status of Hong Kong. In the long run, China has to face the fundamental question of whether the socialist system will be practiced there after 2047. Will China be bound by its promise,

\footnotetext{
${ }^{225}$ Thomas P. Crocker \& Michael P. Hodges, Constitutions, Rule Following, and the Crisis of Constraint, 24 LEGAL THEORY 3, 30 (2018).

${ }^{226}$ Cora Chan, Thirty Years from Tiananmen: China, Hong Kong, and the Ongoing Experiment to Preserve Liberal Values in an Authoritarian State, 17 ICON 439, 443 (2019).

${ }^{227}$ See THE FEDERALIST No. 1 (Alexander Hamilton).

${ }^{228}$ Joel Colon-Rios, What Is a Constitutional Transition?, 37 NAT'L J. Const. L. 43, 47 (2017).
} 
and how will it keep it? As demonstrated, the problem of time, which is common to many constitutional documents, is "the problem of explaining how the majority today can rightfully and legitimately be bound by-held to, against its will-limits on its power enacted generations ago." 229 When the political commitment of "unchanged for 50 years" was enshrined in the constitutional document, the sovereign embraced a sacred mission of maintaining the coexistence of both the capitalist and socialist systems. An idealistic approach to the political commitment is not a competition of superiority of one system over another, but the chance for the peaceful coexistence of the two systems. Constitutional architects of OCTS have thought about the danger of "absorption," "assimilation," or even "intrusion," in the 1980s when Hong Kong was much more economically advanced than the mainland. Deng and other top Chinese leaders rejected the premise that Hong Kong one day would become a "base of subversion" towards socialist China. ${ }^{230}$ Deng's confidence was based on two important considerations. First, a garrison of the PLA would prevent Hong Kong from becoming a "base of subversion." Second, the "reform and opening" of China would make the mainland stronger. Today, China has the world's second largest economy and almost omnipresent influences on Hong Kong. ${ }^{231}$

If there are possibilities for the two systems to coexist, questions on how to maintain the political commitment remain crucial. The fundamental solution to the question lies in constitutionalizing the sacred political commitment and making it extremely hard to alter. Under Chapter VIII of the Basic Law, the Standing Committee of the NPC is vested with the power of interpretation, ${ }^{232}$ while the NPC itself is bestowed with the power of amending the Basic Law. ${ }^{233}$ The language of Article 159 of the Basic Law shows that it is extremely difficult for Hong Kong and China to abolish OCTS unless China fundamentally changes its own constitution. In my view, OCTS as a political commitment must hold true for both Beijing and Hong Kong in 2047 and beyond. There are a number of reasons. First, sustaining OCTS is a political obligation for China. This has been crystalized in the 1984 Joint Declaration and further constitutionalized in the Basic Law. Second, OCTS inherently means that the two systems "should be given their chance and have their way." 234 Third, the fundamental principle of the rule of law must mean that both the powerful and the weak are equally subject to legality. ${ }^{235}$ In this sense, the constitutional principle of OCTS shall be equally binding on both the Hong Kong SAR and the Central People's Government. ${ }^{236}$

\section{Pragmatist Approach}

Political commitments cannot be achieved in a moment. ${ }^{237}$ From a pragmatic point of view, politicians have to consider " $\mathrm{t}]$ he felt necessities of the time." ${ }^{338}$ Contemporary theorists even argue that everyone is virtually compelled to be, on some level, a pragmatist. ${ }^{239}$ A pragmatist approach toward "unchanged for 50 years" is the one that opposes formalistic foundationalists who stick to doctrinal political theories. Foundationalists often focus on laying "bottom brick" for political institutions. As Robert Nozick commented, "when the bottom brick crumbles or is removed, all topples, burying even those insights that were independent of the starting point." ${ }^{240}$ To

\footnotetext{
${ }^{229}$ Jed Rubenfeld, On Fidelity in Constitutional Law, 65 FordHAM L. Rev. 1469, 1480 (1997).

${ }^{230}$ Michael C. Davis, supra note 116, at 173.

${ }^{231}$ Chien Huei Wu, Dance with the Dragon: Closer Economic Integration with China and Deteriorating Democracy and Rule of Law in Taiwan and Hong Kong?, 45 H.K. L.J. 275, 283 (2015).

${ }^{232}$ Basic Law art. 158.

${ }^{233} \mathrm{Id}$. at art. 159.

${ }^{234}$ Gitlow v. New York, 268 U.S. 652 (1925) (Holmes, J. dissenting).

${ }^{235}$ Stephen Thomson, Administrative Law in Hong Kong 30 (2018).

${ }^{236}$ Johannes Chan, A Strained Interpretation of Art 22 of the Basic Law, 50 H.K. L.J. 7, 16 (2020).

${ }^{237}$ Jed Rubenfeld, Reading the Constitution as Spoken, 104 YALE L.J. 1119, 1155 (1995).

${ }^{238}$ Thomas C. Grey, Holmes and Legal Pragmatism, 41 STAN. L. ReV. 787, 793 (1989).

${ }^{239}$ Steven D. Smith, The Pursuit of Pragmatism, 100 YALE L.J. 409, 423 (1990).

${ }^{240}$ Robert Nozick, Philosophical Explanations 3 (1981).
} 
understand the political architects of OCTS, practical wisdom is needed. Before the introduction of OCTS, Mao had adopted "long-term planning, full utilization" toward Hong Kong. That policy was clearly based on a sort of political expediency; it was a de facto recognition of an ideologically different system. By contrast, Deng, as the second generation of China's political leaders, introduced OCTS and gradually turned it into a reality. A pragmatic approach to "unchanged for 50 years" is one which aims to achieve the gradual unification of China. Things have to be done and they must be done step by step. Lord Denning rounded it off in his inimitably graphic way of putting things: "At first a trickle, then a stream, last a flood." ${ }^{211}$ Pragmatists are also incrementalists. They assume that the political evolution at time " 2 " will be better than that of time " 1 " if proper efforts are made. ${ }^{242}$

Pragmatically speaking, "unchanged for 50 years" was the best attainable political commitment made by China to solve the Hong Kong issue. There are several reasons for this. First, "50 years" is based on the necessities at the time for "setting the minds of Hong Kong people at rest." During the 1980s, Hongkongers had a generally anxious way of life given their uncertain future after 1997. Land developers were much more concerned about the land leases by the colonial government. Second, "50 years" is in line with China's ambitious development strategy aiming to revitalize its past glory as a shining civilization. In Deng's mind, China needs a stable and prosperous Taiwan and Hong Kong from roughly 2000 to 2050. Third, by the middle of the twenty-first century, mainland China will achieve the same level of economic development as Hong Kong, and, by that time, China will have several cities comparable to Hong Kong. Deng's remarks in 1984 and 1988 support the assertion that " 50 years" was the best, attainable political commitment made by China. ${ }^{243}$ For Deng, " 50 years is a vivid saying, after 50 years, the policy will not be changed. For the first 50 years, it cannot be changed, for the time after 50 years, there is no need for changes." 244 Besides that, "unchanged for 50 years" can also be treated as a matter of political expediency. Historical records show that "unchanged for 30 years" was actually proposed during the early 1980s, but it was promptly given up, as 30 years was too short to achieve the desired political outcomes. With practical wisdom, there are many occasions for our generations to fulfill the expedient objectives of the political commitment.

Because political commitments can be dressed in legal forms, ${ }^{245}$ a pragmatist approach is also frequently adopted in constitutional interpretation under the Basic Law. For China, the institution that best understands the law is the one that enacted the law. ${ }^{246}$ Ever since the first NPCSC's Interpretation was issued in $1999,{ }^{247} \mathrm{CFA}$ adopted a pragmatic view and was keenly conscious of the consequences of its actions. ${ }^{248}$

\section{Critiques}

"Unchanged for 50 years," as a political commitment made by China, is a constitution designed at the very top. As the Federalist Papers correctly show, the subject speaks to its own importance. With special references to the founding fathers of the world's oldest written constitutionHamilton and Madison-one may approach constitution-making as a human endeavor for a

\footnotetext{
${ }^{241}$ Democratic Republic of the Congo v. FG Hemisphere Assoc., LLC, [2011] H.K.C.F.A.R 41, para. 67 (C.F.A.).

${ }^{242}$ See Levinson, supra note 215 , at 674.

${ }^{243}$ Deng Xiaoping, supra note 218 , at 102-03, 267.

${ }^{244} I d$. at 267.

${ }^{245}$ Thomas D. Grant, The Budapest Memorandum of 5 December 1994: Political Engagement or Legal Obligation?, 34 POLISH Y.B. INT'L L. 89, 102 (2014).

${ }^{246}$ Anthony Mason, The Rule of Law in the Shadow of the Giant: The Hong Kong Experience, 33 SyDnEY L. REV. 623,629 (2011).

${ }^{247}$ China: Interpretation by the Standing Committee of the National People's Congress of Articles 22(4) and 24(2)(3) of the Basic Law of the Hong Kong Special Administrative Region of the People's Republic of China, June 26, 1999, 38 I.L.M. 1469.

${ }^{248}$ Po Jen Yap, Twenty Years of the Basic Law: Continuity and Changes in the Geoffrey Ma Court, 49 H.K. L.J. 209, 209-10 (2019).
} 
new republic. The making of Hong Kong's Basic Law is obviously not comparable to what Madison termed a "large republic," because Hong Kong does not possess a great number of citizens and a great amount of land. What's more, unlike other constitutions, it is not self-authored by an independent, sovereign people. Thus, the Basic Law is a delegation of autonomy to a special administrative region, not a sovereign act of self-definition. ${ }^{249}$ Based on these reasons, there are serious criticisms toward both the idealist approach and the pragmatist approach.

The differences between the idealist approach and the pragmatist approach can be described as the "difference between ideals and needs." ${ }^{250}$ However, more difficult questions may appear. As Levinson suggests: (1) How can later generations know that political decision at time " 1 " is better than political decision at time "2"?;and (2) "Should the political decision at time "2" effectively be bound by political decisions made at time " 1 "? ${ }^{251}$ As for the first question, the pragmatist's argument of "necessities at the time" cannot justify the fact that the political decision in the 1980s is better than another one made later in history. How can we predict that the continuation of "unchanged for 50 years" after 2047 is a better one? As for the second question, it is more of a fundamental question of "why should we allow the dead to rule the living?" This was asked by Thomas Jefferson. ${ }^{252}$

While the idealists focus too much on China's political commitments to retain the system after 2047, pragmatists may also neglect the new political realities in 2047. Dworkin in Law's Empire develops his arguments against legal pragmatism based on three competing theories: Conventionalism, pragmatism, and law as integrity. ${ }^{253}$ As for the pragmatist, they may make instrumental use of the past in promoting future good. ${ }^{254}$ Dworkin himself refused to recognize those approaches adequate enough to show what the law is. The constitutional design of OCTS allows Hong Kong's previous common law to remain basically unchanged. Pragmatists have given special regard to the writings of Deng because Deng was so instrumental during the constitutionmaking of Hong Kong. But that does not guarantee a continuation of OCTS when China's great centennial project finishes successfully around 2047. Additionally, China can abolish its previous Hong Kong policies, including "unchanged for 50 years," when fundamental circumstances occur.

\section{III. "Unchanged for 50 Years" as Constitutional Obligation}

Constitutions set out the mechanisms by which laws become binding, and they further entail more general political obligations. ${ }^{255}$ The hallmark of modern constitutional theories is to design a democratic constitutional framework under which arbitrary political power is subject to the rule of law. Before July 1, 1997, exiguous as they are, the Letters Patent provided Hong Kong the source of constitution under which the colonial governor derived his power as a servant of the Crown. ${ }^{256}$ Since the establishment of the SAR, many Hong Kong constitutional theorists depict the Basic Law like the two-faced Roman god Janus. The Basic Law has a duality in that it is law both in the jurisdiction that establishes it (China) and in the jurisdiction it establishes (Hong Kong). ${ }^{257}$ The duality of the Basic Law makes it sui generis, ${ }^{258}$ calling for principles of interpretation of its own. ${ }^{259}$

\footnotetext{
${ }^{249}$ Fiss, supra note 113 , at 497.

${ }^{250}$ Anthony T. Kronman, Alexander Bickel's Philosophy of Prudence, 94 YALE L.J. 1567, 1578 (1985).

${ }^{251}$ Levinson, supra note 215 , at 676.

${ }^{252}$ David A. Strauss, Why Conservatives Shouldn't Be Originalists, 31 HARV. J. L. \& PUB. POL'Y 969, 972 (2008).

${ }^{253}$ Steven D. Smith, The Pursuit of Pragmatism, 100 YALE L.J. 409, 414 (1990).

${ }^{254} \mathrm{Id}$.

${ }^{255}$ Louis M. Seidman, Political and Constitutional Obligation, 93 B.U. L. Rev. 1257, 1279-80 (2013).

${ }^{256}$ Attorney General v. Chiu Tat-Cheong, [1992] 2 H.K.L.R. 84, 107 (C.A.).

${ }^{257}$ Lo Pui Yin, The Judicial Construction of Hong Kong's Basic Law: Courts, Politics and Society After 19973 (2014) (recognizing "the dual nature of the Basic Law as being a piece of domestic law in the Mainland and a constitution in the HKSAR"). See also Tai, supra note 9, at 503.

${ }^{258}$ R. v. Sin Yau Ming, [1991] 1 H.K.C. 289, 31 (C.A.).

${ }^{259}$ Minister of Home Affairs v. Fisher [1980] 1 AC 319, 328-29 (PC) (appeal taken from Bermuda).
} 
"Unchanged for 50 years" is a clause provided in Chapter I of the Basic Law, which contains eleven articles that state general constitutional principles. ${ }^{260}$ Article 1 provides that the HKSAR is an inalienable part of the PRC. Article 2 authorizes the HKSAR to exercise a high degree of autonomy and enjoy executive, legislative, and independent judicial power, including that of final adjudication, in accordance with the provisions of the Basic Law. Article 5 provides that "socialist system and policies" shall not be practiced in the region, and that the previous capitalist system and way of life shall remain unchanged for 50 years. ${ }^{261}$ Besides the general provisions, it is equally important to keep in mind that the preamble of the Basic Law mentions the principle of OCTS without any explicit time limit. Chinese scholars generally consider this provision of "great importance," that China must adhere to. ${ }^{262}$ How should we interpret the phrase "unchanged for 50 years" in Article 5 of the Basic Law? What exactly does the reference to " 50 years" mean? Should it be construed as an explicit time limit or should we interpret it as the continuation of OCTS without an explicit time limit? And why would the authors of the Basic Law create such a phrase in Article 5-a phrase that is unfamiliar to the preamble of the Basic Law ?The answers to these questions not only help us understand the nature of the Basic Law, but also provide us with insight into the constitutional future of Hong Kong after 2047.

Although much of the common law inheritance from the constitution, in all its mazy nature, ${ }^{263}$ remained unchanged in Hong Kong after the handover, the Basic Law was not drafted by common law lawyers. It was drafted in the Chinese language with an official English version, but the Chinese version takes precedence in case of discrepancies. ${ }^{264}$ HKSAR v. Ma Wai Kwan David was the first case in which the High Court recognized the three dimensions of the Basic Law: International, domestic, and constitutional. ${ }^{265}$ It was in $\mathrm{Ng} \mathrm{Ka} \mathrm{Ling} v$. Director of Immigration that questions involving the proper interpretation of the Basic Law were addressed for the first time by the highest judiciary in Hong Kong, the CFA. ${ }^{266}$ Hong Kong's first post-1997 Chief Justice, Andrew Li, made it fairly clear: "These are questions of momentous importance for both the future of the people involved as well as the development of constitutional jurisprudence in the new order." 267

Generated by the 2014 Occupy Central Movement and the 2019 Extradition Bill Crisis, questions regarding the momentary nature and temporality of OCTS have been increasingly raised. Strong sentiments of pessimism were felt in the general public, not only among the younger generations of Hongkongers but also for many liberals in the mainland. Moreover, concern for Hong Kong's future spread in the international media. Former Chief Justice Andrew Li suggested that the question of 2047 "will have to be discussed and settled within one country" around the year $2030 .{ }^{268}$ I hereby argue that understanding "unchanged for 50 years" as a constitutional obligation requires courageous and bold intellectual efforts to patrol the borders of modern Chinese constitutional jurisprudence. Originalism and living constitutionalism are among the most commonly used approaches for the interpretation of the Basic Law.

\footnotetext{
${ }^{260} \mathrm{Ng}$ Ka Ling Case at 12.

${ }^{261} I d$.

${ }^{262}$ WANG, supra note 102, at 363 ("The laws currently in force in Hong Kong after the handover remain basically unchanged and at the same time, Hong Kong retains the status of a free port and a separate customs territory.").

${ }^{263}$ See John O. McGinnis, The Duty of Clarity, 84 GeO. WASH. L. Rev. 843, 919 (2016).

${ }^{264} \mathrm{Ma}$ Wai Kwan David Case at para. 14.

${ }^{265} \mathrm{Id}$.

${ }^{266} \mathrm{Ng}$ Ka Ling Case at 3.

${ }^{267} \mathrm{Id}$. at 3.

${ }^{268}$ GitTINGS, surpa note 8 , at 318 .
} 


\section{Originalism Approach}

It is pointed out that originalism blossoms in a nation when a political leader associated with the creation or revision of the nation's constitution develops a cult of personality. ${ }^{269}$ This cult of personality theory can largely explain the constitutional history of Mao's China, and it remains the case for an appropriate understanding of Deng's constitutional design of OCTS. Returning to discourse centered on Deng's remarks during the 1980s strengthened whenever there was a constitutional or political crisis in Hong Kong. A recent conference organized by the Chinese Association of Hong Kong \& Macao Studies on revisiting Deng's remarks on the issue of Hong Kong is a good example of China's originalist approach toward Hong Kong's 2019 Extradition Bill Crisis. ${ }^{270}$ The originalism approach suggests that OCTS shall remain constitutionally in force long beyond its initial 50-year period.

Originalists argue that deference to the original understandings or expectations with respect to the Constitution can answer the challenges people face. ${ }^{271}$ For Justice Scalia, originalism seems to be more compatible with the nature and purpose of a constitution in a democratic system. ${ }^{272}$ Interpretation is just a matter of honoring constitutional commitments and furthering constitutional ends. ${ }^{273} \mathrm{~A}$ brief survey of originalism shows that the conception itself is disputed in different contexts $^{274}$ and there are different versions of originalism. Strict originalism argues for founders' specific value judgments which then determine constitutional meaning. ${ }^{275}$ Moderate originalism argues that the meaning of the constitution shall be determined by what Michael J. Perry calls "directives," a set of principles or rules that are to be taken as authoritative. ${ }^{276}$ Strict originalism tends to treat the constitution as a book of answers, and moderate originalism deems it a book of aspirations. ${ }^{277}$ There are also other categorizations of originalism as "original intent" originalism and "public meaning" originalism. ${ }^{278}$ Fleming and Dworkin have given room for a moral reading of constitutional interpretation, and for them, "fidelity to our imperfect Constitution entails fidelity in pursuit of our constitutional aspirations and ends." 279

It is hard to say that Chinese constitutional jurisprudence has developed sophisticated debates between strict originalism and moderate originalism. Many of the arguments are actually politicized, which largely reflects the incumbent governmental positions. Nevertheless, the originalism approach to Basic Law interpretation encourages and fosters a proper or even precise understanding of the meaning of "unchanged for 50 years" by tracing the historical records of the founders and drafters. I hereby present three arguments for an originalist interpretation of the "unchanged for 50 years" clause under Article 5 of the Basic Law.

First, originalists argue that the some of the founders' critical original wording has shown clear intent not to construct Article 5 as a sunset clause. There is no other source of legislative intent that supports setting a 2047 time limit on OCTS. When the Basic Law Drafting Committee was at

\footnotetext{
${ }^{269}$ Ozan O. Varol, The Origins and Limits of Originalism: A Comparative Study, 44 VAND. J. TranSNAT'L L. 1239,1240 (2011).

${ }^{270}$ Ma Junqing, Review Comrade Deng Xiaoping's Important Speech on Hong Kong Issues, XINHUANET (Aug. 25, 2019), http://www.xinhuanet.com//2019-08/25/c_1124917136.htm.

${ }^{271}$ André LeDuc, Originalism's Claims and Their Implications, 70 ARK. L. Rev. 1007, 1007 (2018).

${ }^{272}$ Antonin Scalia, Originalism: The Lesser Evil, 57 U. CIN. L. REv. 849, 862 (1989).

${ }^{273}$ James E. Fleming, Fit, Justification, and Fidelity in Constitutional Interpretation, 93 B.U. L. REV. 1283, 1288-87, 1296 (2013).

${ }^{274}$ Lawrence B. Solum, Originalism Versus Living Constitutionalism: The Conceptual Structure of the Great Debate, 113 Nw. U. L. REV. 1243, 1250 (2019).

${ }^{275}$ Richard B. Saphire, Originalism and the Importance of Constitutional Aspirations, 24 Hastings ConsT. L.Q. 599, 610 (1997).

${ }^{276} \mathrm{Id}$. at 611 .

${ }^{277}$ Michael J. Perry, Morality, Politics ANd Law 139 (1988); Saphire, supra note 275, at 634.

${ }^{278}$ Robert J. Delahunty \& John Yoo, Saving Originalism, 113 MicH. L. Rev. 1081, 1096, 1100 (2015).

${ }^{279}$ Fleming, supra note 273 , at 1296.
} 
work, Deng Xiaoping, the paramount constitutional architect, addressed the committee on April 16,1987 by stating the following:

Try to imagine what would happen to Hong Kong if China changed its socialist system, the socialist system with Chinese characteristics under the leadership of the Communist Party. That would be the end of prosperity and stability for Hong Kong. To make sure the policy remains unchanged for 50 years and beyond, we must keep the socialist system on the Mainland unchanged .... There are also two aspects to the policy of "one country, two systems." One is that the socialist country allows certain special regions to retain the capitalist system-not just for a short period of time, but for decades or even a century. The other is that the main part of the country continues under the socialist system. Otherwise, how could we say there were "two systems?" It would only be "one system." People who advocate bourgeois liberalization hope that the Mainland will become capitalist or "totally Westernized." Our thinking on this question should not be one-sided. If we don't attach equal importance to both aspects, it will be impossible to keep the policy of "one country, two systems" unchanged for several decades. ${ }^{280}$

Later, in 1988, Deng further clarified the meaning of "unchanged for 50 years" at an international conference: "As a matter of fact, 50 years is only a vivid way of putting it. Even after 50 years our policy will not change either. That is, for the first 50 years it cannot be changed and for the second there will be no need to change it." 281

As Justice Scalia held, "the meaning of a word cannot be determined in isolation, but must be drawn from the context in which it is used." 282 The CFA took the same stance in the Chong Fung Yuen case as Justice Scalia did. ${ }^{283}$ In the $\mathrm{Ng} \mathrm{Ka}$ Ling case, the CFA treated context as being particularly important in the interpretation of a constitutional instrument. ${ }^{284}$ The $\mathrm{Ng} \mathrm{Ka} \mathrm{Ling} \mathrm{case}$ demonstrates that the "interpretation [of] the purpose of a particular provision may be ascertainable from its nature or other provisions of the Basic Law or relevant extrinsic materials including the Joint Declaration." 285 As to the language of its text, the courts "must avoid a literal, technical, narrow or rigid approach. They must consider the context. The context of a particular provision is to be found in the Basic Law itself as well as relevant extrinsic materials including the Joint Declaration." ${ }^{286}$ What's more, the $\mathrm{Ng} \mathrm{Ka}$ Ling case referred to extrinsic materials as aids for searching for the original intent of the Basic Law. The CFA in the Chong Fung Yuen case stressed the importance of internal materials which aid constitutional interpretation:

[I]t is sufficient to state that on the common law approach which the courts are bound to apply in the absence of a binding interpretation by the Standing Committee, extrinsic materials, whatever their nature and whether pre or post-enactment, cannot affect interpretation where the courts conclude that the meaning of the language, when construed in the light of its context and purpose ascertained with the benefit of internal aids and appropriate extrinsic materials, is clear. ${ }^{287}$

\footnotetext{
${ }^{280}$ XIAOPING, supra note 103 , at $49-54$.

${ }^{281} I d$. at 61 .

${ }^{282}$ Deal v. United States, 508 U.S. 129, 132 (1993).

${ }^{283}$ Chong Fung Yuen Case at 223.

${ }^{284} \mathrm{Ng} \mathrm{Ka}$ Ling Case at 74.

${ }^{285} \mathrm{Id}$. at 75

${ }^{286} \mathrm{Ng}$ Ka Ling Case at 76.

${ }^{287}$ Chong Fung Yuen Case at 6.3.
} 
Both the extrinsic materials and internal materials indicate that it seems unlikely that Article 5 of the Basic Law was ever intended to provide for an automatic end to OCTS and the imposition of a socialist system in Hong Kong after June 30, 2047. ${ }^{288}$

Second, originalists argue that it is the collective understanding of the Hong Kong issue in its particular circumstances which requires us not to fundamentally alter or abolish OCTS beyond 2047. As Annaleigh E. Curtis put it, "words do not have meanings beyond how they are used in particular social contexts." 289 The question for understanding has thus become the collective understanding of "unchanged for 50 years" at the time the Basic Law was enacted. Sometimes people resort to corpus lexicography for the resolution of their disagreements of semantic meanings, but this is unsatisfying in many cases. ${ }^{290}$ This is because the meaning of language changes, and the most frequent usage might be wrong. ${ }^{291}$ As the CFA held in the Chong Fung Yuen case, the context and purpose of the Basic Law was established at the time of its enactment in $1990 .^{292}$ Therefore, it is more proper to construe the meaning of "unchanged for 50 years" by exploring the intent and purpose of 1990. The great danger for originalists here is the juxtaposition of the collective understanding in 1990 and ours at this moment. It is argued here that the collective understanding of "unchanged for 50 years" in 1990 did not include a clear time limit for OCTS. One may well question why, in the year of 1990, is it made "50 years?" Why not "30 years" or "100 years?" Deng once said that OCTS was not just for a short period of time, but for decades or even a century. The draft of the Basic Law was passed by the NPC with ninety-eight percent of votes in favor. This all prove that a time limit on OCTS in Hong Kong was never intended.

Third, originalists argue that June 30, 2047 was not designed, and should not be interpreted, as the expiration date for OCTS. Given that the Basic Law translates the basic policies enshrined in the Joint Declaration into more practical terms, ${ }^{293}$ the date of June 30, 2047 under Annex III of the Joint Declaration has some bearings on the "unchanged for 50 years" clause, The "unchanged for 50 years" clause is a general rule as to it intends applications under both the Joint Declaration and Article 5 of the Basic Law. Meanwhile, the "June 30, 2047" clause under the Joint Declaration is a rule of specification that particularly deals with land lease issues. A general rule guided by general principles dealing with specific situations must be observed. In other words, it is vital for us to make a distinction between the "unchanged for 50 years" clause and the mentioning of "June 30, 2047" in land issues, even though the latter is inevitably intertwined with the former. Actually, a great number of land leases now extend well beyond June 30, 2014 in Hong Kong. A notable example is the land used to construct the Hong Kong Disneyland theme park, which includes a right to renew the lease for a second 50-year period-a right that would allow the lease to continue until $2100 .{ }^{294}$ As facts do not necessarily justify what the "law ought to be," permissible land leases beyond June 30, 2014 certainly do not provide the normative constitutional obligations under the "Unchanged for 50 years" clause. In the $\mathrm{Ng} \mathrm{Ka}$ Ling case, it is the view of the CFA that the Basic Law was enacted to implement China's basic policies regarding Hong Kong to remain unchanged for 50 years as declared and elaborated in the Joint Declaration. ${ }^{295}$ The court further proclaimed that Article 4 of the Basic Law provides that no amendment thereto shall contravene the established basic policies. ${ }^{296}$ Chief Justice Chan of the High Court stated in 1997 in HKSAR v. Ma Wai Kwan David that:

\footnotetext{
${ }^{288}$ GitTings, supra note 8, at 50.

${ }^{289}$ Annaleigh E. Curtis, Why Originalism Needs Critical Theory: Democracy, Language, and Social Power, 38 HARV. J. L. \& GENDER 437, 441 (2015).

${ }^{290}$ Solum, supra note 274 , at 1253.

${ }^{291} I d$.

${ }^{292}$ Chong Fung Yuen Case at 6.3.

${ }^{293} \mathrm{Ma}$ Wai Kwan David Case at para. 13.

${ }^{294}$ GITTINGS, supra note 8 , at 316.

${ }^{295} \mathrm{Ng}$ Ka Ling Case at 65.

${ }^{296} I d$.
} 
[T] he essence of these policies is that the current social, economic, and legal systems in Hong Kong will remain unchanged for 50 years. The purpose of the Basic Law is to ensure that these basic policies are implemented and that there can be continued stability and prosperity for the HKSAR. ${ }^{297}$

Combined with all these reasons, it can be deduced that continuity after the change of sovereignty is therefore of vital importance. June 30, 2047 is not the expiration date for OCTS in Hong Kong.

\section{Living Constitutionalism Approach}

The benefits of originalism lead us to search for a correct understanding of the constitutional text. However, as Heraclitus famously said, "everything is in flux and nothing is at rest." 298 Even the utmost adherents of originalism cannot deny that it is a constitution that "we the people" are constantly amending. By doing so, we periodically become wise framers ourselves. ${ }^{299}$ A constitution can adapt itself in a changing society. Fundamental changes in the constitutional order occur without formal textual amendments to the constitution. ${ }^{300}$ In defending living constitutionalism, Bruce Ackerman once said, "[h]istory doesn't repeat itself; but it is all we have, and it is a precious source of constitutional precedents that we can, in common law fashion, apply to our recent past and changing future." ${ }^{301}$ David A. Strauss has set forth what has quickly become the theory's leading account in his book called A Living Constitution. ${ }^{302}$ For Strauss, due to problems of ascertainment, indeterminacy, and translation, originalism imposes only a very uncertain limit on judges and leaves them a great deal of latitude to find, in the original understandings, the outcomes they want to find. ${ }^{303}$ In McCulloch v. Maryland, Justice John Marshall wrote:

A constitution, to contain an accurate detail of all the subdivisions of which its great powers will admit, and of all the means by which they may be carried into execution, would partake of the prolixity of a legal code, and could scarcely be embraced by the human mind. It would, probably, never be understood by the public. Its nature, therefore, requires, that only its great outlines should be marked, its important objects designated, and the minor ingredients which compose those objects, be deduced from the nature of the objects themselves. . . . [W] e must never forget that it is a constitution we are expounding. ${ }^{304}$

The unanimous opinion by the U.S. Supreme Court on the constitutional interpretation of the Necessary and Proper Clause gained general acceptance. Scholars describe this opinion as the pioneer of living constitutionalism. ${ }^{305}$ In Missouri $v$. Holland, the court reiterated that the constitution has to deal with situations "which could not have been foreseen completely by the most gifted of its begetters." ${ }^{306}$ Justice Holmes famously said, "the present has a right to govern itself so far as it can; and it ought always to be remembered that historic continuity with the past is not a duty, it is only a necessity." 307

\footnotetext{
${ }^{297} \mathrm{Ma}$ Wai Kwan David Case at para. 13.

${ }^{298}$ Karl R. Popper, The Open Society And Its Enemies, 11-17 (5th ed. 1966).

${ }^{299}$ John O. McGinnis, The Original Constitution and Its Decline: A Public Choice Perspective, 21 HarV. J.L. \& PUB. POL'Y 195, 209 (1997).

${ }^{300}$ David A. Strauss, The Irrelevance of Constitutional Amendments, 114 HARV. L. REv. 1457, 1505 (2001).

${ }^{301}$ Bruce Ackerman, The Living Constitution, 120 HARV. L. REv. 1737, 1811 (2007).

${ }^{302}$ Justin Driver, The Significance of the Frontier in American Constitutional Law, 2011 SuP. CT. REv. 345, 349 (2011).

${ }^{303}$ Strauss, supra note 252 , at $970-73$.

${ }^{304} \mathrm{McCulloch}$ v. Maryland, 17 U.S. 316, 407 (1819).

${ }^{305}$ John F. Manning, The Role of the Philadelphia Convention in Constitutional Adjudication, 80 GEO. WASH. L. REv. 1753, 1774 (2012).

${ }^{306}$ Missouri v. Holland, 252 U.S. 416, 433 (1920).

${ }^{307}$ Oliver Wendell Holmes, Learning and Science, in Collected Legal Papers 138, 139 (1920).
} 
Under the common law tradition, courts in Hong Kong are committed to what Lord Wilberforce calls a generous interpretation approach, which avoids what has been called "the austerity of tabulated legalism." ${ }^{308}$ During Hong Kong's late colonial era, in Attorney General v. David Chiu Tat-cheong, the Court of Appeals was requested to decide whether the Governor's power to appoint magistrates was capable of delegation. In its decision, the court felt it was obligated to follow the constitutional jurisprudence of Lord Sankey, L.C. in Edwards v. Attorney General of Canada which held that " $\mathrm{t}]$ he British North America Act planted in Canada a living tree capable of growth and expansion within its natural limits, and like all written constitutions it has been subject to development through usage and convention." ${ }^{309}$ In the case of David Chiu Tat-cheong, the Hong Kong court adopted a generous and purposive approach that followed Lord Wilberforce's observation in Minister of Home Affairs v. Fisher ${ }^{310}$ and Lord Diplock's comment in Attorney General of The Gambia v. Momodou Jobe. ${ }^{311}$ This generous approach is especially applicable when common law courts interpret fundamental rights protections. ${ }^{312}$

After the handover, the principles of interpretation of the Basic Law were authoritatively laid down in several landmark constitutional decisions, such as the $\mathrm{Ng} \mathrm{Ka} \mathrm{Ling} \mathrm{case} \mathrm{in} \mathrm{1999,} \mathrm{the} \mathrm{Chong}$ Fung Yuen case in 2001, and the Vallejos case in 2013, issued by the CFA. It is highlighted by the CFA that, as is usual for constitutional instruments, the Basic Law uses ample and general language. It is a living instrument intended to meet changing needs and circumstances. ${ }^{313}$ However, Basic Law interpretation is a matter of great controversy after the handover because there are different institutions that may have a say concerning these matters. Article 158(1) of the Basic Law laid out the foundation for the NPC's ultimate power of interpreting the Basic Law. Meanwhile, Article 158(2) mandates the Hong Kong courts to interpret provisions that fall within Hong Kong's autonomy on their own. ${ }^{314}$ The power of final adjudication in Hong Kong does not include the power of final interpretation. ${ }^{315}$ Interpretation by the NPC, a political body under the control of the Central People's Government and the CCP, ${ }^{316}$ has led to some debates because the demarcation between the NPC's interpretation and Hong Kong's judicial interpretation needs to be drawn. In the Vallejos case, it is articulated by the CFA that when the conditions of classification, necessity, and arguability under Article 158(3) are satisfied, then and only then must the CFA make a reference to the Standing Committee of the NPC. ${ }^{317}$ This has been consistent with the court's decision in the $\mathrm{Ng} \mathrm{Ka} \mathrm{Ling} \mathrm{case}{ }^{318}$ and the Congo case. ${ }^{319}$ All in all, it is within the power of the NPC, which has the ultimate authority to interpret the Basic Law. ${ }^{320}$ Sir Anthony Mason prescribes this as "according to Chinese jurisprudence, the institution which best understands what the legislative intention was, is the institution which enacted the law." ${ }^{21}$

The living constitutionalism approach toward "unchanged for 50 years" suggests that interpretation of the Basic Law should meet changing needs and circumstances. There are large volumes of literature regarding OCTS, but what many observers and commentators neglected is the historical

\footnotetext{
${ }^{308}$ Minister of Home Affairs, 1 AC at 328-29.

${ }^{309}$ Edwards v. Canada (AG) [1930] 1 AC 124, 136-37 (PC) (appeal taken from S.C.C.).

${ }^{310}$ Minister of Home Affairs, $1 \mathrm{AC}$ at $328-29$.

${ }^{311}$ Gambia (AG) v. Momodou Jobe [1984] 1 AC 689, 700 (PC) (appeal taken from Gambia).

${ }^{312}$ Ex parte Kebeline, [2000] 2 AC 326 (HL) 375 (appeal taken from Eng.); In the Matter of an Application by the Northern Ireland Human Rights Commission for Judicial Review, [2018] UKSC 27, para. 212.

${ }^{313} \mathrm{Ng}$ Ka Ling Case at 73.

${ }^{314}$ GITTINGS, supra note 8 , at 222.

${ }^{315}$ Mason, supra note 246 , at 644 .

${ }^{316}$ Johannes M.M. Chan, H.L. Fu \& Yash Ghai, Hong Kong's Constitutional Debate: Conflict Over INTERPRETATION 36 (2000).

${ }^{317}$ Vallejos Evangeline Banao v. Commissioner of Registration, [2013] 16 H.K.C.F.A.R. 45, 105 (C.F.A.)

${ }^{318} \mathrm{Ng}$ Ka Ling Case at 89.

${ }^{319}$ Democratic Republic of Congo v. FG Hemisphere Associates, [2011] H.K.C.F.A.R. 41, 517 (C.F.A.).

${ }^{320}$ Lau Kong Yung v. Director of Immigration, [1999] 2 H.K.C.F.A.R. 300, 57 (C.F.A.).

${ }^{321}$ Mason, supra note 246, at 629.
} 
and economic development of Shenzhen, a neighboring city of Hong Kong, which has been booming during the last four decades. By the year 2047, mainland China is anticipated to have reached the same level of economic development as Hong Kong. ${ }^{322}$ Some mainland Chinese scholars have suggested that OCTS will have outlived its usefulness by 2047 and should be abolished altogether. ${ }^{323}$ China's 2014 White Paper represents a major shift of the gravity of OCTS. Hong Kong's autonomy, as it reiterated, was not akin to that experienced by a province or state within a federal structure. Autonomy is not an inherent power, but one that comes solely from authorization by the central leadership. The high degree of the HKSAR's autonomy is not full autonomy, nor a decentralized power. Rather, it is the power to run local affairs as authorized by the central leadership. The high degree of HKSAR's autonomy is subject to the level of the central leadership's authorization. There is no such thing as "residual power." 324 The White Paper continues: The "one country" is the premise and basis of the "two systems," and the "two systems" are subordinate to and derived from "one country." 325 It is held by international commentators that the passage implied that Hong Kong's autonomy could theoretically be withdrawn before the fifty-year period was up. ${ }^{326}$

Any academic discussions of the Basic Law without some understanding of the growing influences of mainland China would serve to ignore the elephant in the room. It would be inappropriate to adhere to particular doctrines or visions that one happens to cherish or that one believes to have been enshrined in the Basic Law. ${ }^{327}$ Promise, stability, certainty, and predictability, even if required by any society based on the rule of law, are not all of the story of the law's true life. The Basic Law is a living tree. When it was made, it was not intended to be frozen, and the Basic Law is a living constitution that the people are constantly making and remaking. Furthermore, no one would deny that the circumstances of the second half of the twenty-first century will remain unchanged. Just as the destruction of the Second Temple and the displacement of the Jewish People in the Galut (exile) were not the end of the Jewish people, ${ }^{328}$ the continuing and will-be-continuing controversies over Hong Kong's constitutional fate are not and will not be the end of the great journey of the people of Hong Kong.

\section{Critiques}

Thomas Jefferson has put forward one of the fundamental questions of constitution law: Why should we allow the dead to rule the living? ${ }^{329}$ To answer that great question, different constitutional approaches lead to different responses. Originalism and living constitutionalism are to be considered as the only valid theories about constitutional interpretation. ${ }^{330}$ Recent research shows that attempts to provide conceptual clarity to the great debate between originalism and living constitutionalism face many obstacles. ${ }^{331}$ As Lawrence B. Solum demonstrates, one of the most widely misunderstood views is that of equating originalism as static and living constitutionalism as dynamic. As for the constitutional interpretation of "unchanged for 50 years," both originalism and living constitutionalism shed light for clarifying the normative ambiguity of China's

\footnotetext{
${ }^{322}$ GitTings, supra note 8 , at 321 .

${ }^{323} \mathrm{Id}$. at 320 .

${ }^{324} 2014$ White Paper.

${ }^{325} \mathrm{Id}$.

${ }^{326}$ Hargreaves, supra note 53, at 549.

${ }^{327}$ Yee, supra note 8, at 236.

${ }^{328}$ Joshua Segev, Who Needs a Constitution? In Defense of the Non-Decision Constitution-Making Tactic in Israel, 70 ALB. L. REV. 409, 412 (2007).

${ }^{329}$ Strauss, supra note 252 , at 972 .

${ }^{330}$ Artour Rostorotski, David A. Strauss' the Living Constitution (2010), 12 German L.J. 1545, 1550 (2011) (reviewing Daniel A. Strauss, The Living Constitution (2010)).

${ }^{331}$ Solum, supra note 274 , at 1248.
} 
constitutional obligations toward 2047. However, the two approaches toward constitutional interpretation of the Basic Law are not perfect and thus are subject to critiques.

As for the originalism approach, despite the fact that recourse to historical records is common, there are critiques of this approach based on a number of reasons. The first is a philosophical one which says that the approach commits a nation to being ruled by the dead hand of the past in an evolving society. ${ }^{332}$ Recent years has also seen that many have grown skeptical of the relevance of Max Farrand's Records of the Federal Convention of 1787 to unearthing constitutional meaning. ${ }^{333}$ Greene rejects interpretive obligation in constitutional law. For him, constitutional interpreters need not follow either prior or higher sources of purported interpretive authority, even presumptively. ${ }^{334}$ What's more, Seidman also agrees that present day constitutional interpreters are not bound to prior sources of constitutional meaning. ${ }^{335}$ First, one may question why the original intent of Basic Law binds later generations after 2047. Second, the paucity of primary evidence in the constitution-making process has made it difficult to grasp the precise meaning of the opentext provisions. ${ }^{336}$ In fact, the Sino-British negotiations were conducted on a basis of confidentiality. ${ }^{337}$ Limited released historical records of the pre-enactment materials have posed challenges for those ambitious constitutional theorists. Searching for the original meaning sometimes becomes merely a speculation or guess. Third, constitutional lawyers are unable to have the final say on the validity of those historical records. Just as Justice Scalia conceded, "collecting and identifying historical records was primarily a task sometimes better suited to the historian than the lawyer." 338

As for the approach of living constitutionalism, there are also many deadly challenges. The first would be to say that the adaptability of the Basic Law makes OCTS functioning in a fast-paced society. When interpreting "unchanged for 50 years," respects must be paid to the language that has been used and to the traditions and usages that have given meaning to that language. ${ }^{339}$ Otherwise, legal certainty and continuity would be lost in the operation of OCTS. Second, applying living constitutionalism toward Article 5 of the Basic Law also causes concerns about constitutional endurance. As Zachary Elkins, Tom Ginsburg, and James Melton show, three mutually reinforcing features-inclusion, flexibility, and specificity-can enhance the probability that a constitution will endure. ${ }^{340}$ Richard Albert further argues that constitutional states prefer to retain legal continuity, which will lead to constitutional endurance. ${ }^{341}$ The 2047 guarantee had never previously been interpreted as something that was anything less than ironclad. Hongkongers lived with the terms of the Joint Declaration and the Basic Law. Their basic system of government and laws were protected from interference until 2047. Neither of those documents had been contingent on this matter of "respect." Equally troubling is the White Paper's ambiguous reference to a kind of "patriotism test" for those seeking office, including judicial posts, ${ }^{342}$ but this does signify China's abandonment of OCTS.

\footnotetext{
${ }^{332}$ Varol, supra note 269 , at 1287.

${ }^{333}$ Manning, supra note 305, at 1754.

${ }^{334}$ Abner S. Greene, What Is Constitutional Obligation?, 93 B.U. L. REV. 1239, 1240 (2013).

${ }^{335} \mathrm{Id}$.

${ }^{336}$ Varol, supra note 269 , at 1240.

${ }^{337} 1984$ Joint Declaration at $1368-69$.

${ }^{338}$ Scalia, supra note 272 , at 857.

${ }^{339}$ Minister of Home Affairs v. Fisher, [1980] 1 AC 319, 328-29 (PC) (appeal taken from Bermuda).

${ }^{340}$ Zachary Elkins, Tom Ginsburg \& James Melton, The Endurance of National Constitutions 78-92 (2009).

${ }^{341}$ Richard Albert, Constitutional Amendment and Dismemberment, 43 YALE J. INT'L L. 1, 73 (2018).

${ }^{342}$ Hargreaves, supra note 53 , at 549.
} 


\section{E. Conclusion}

It took nearly a century for Hong Kong to transform itself from "a barren rock" to an international financial center. ${ }^{343}$ In a time of change, most Hongkongers, as Chinese, have been struggling with their own cultural and political identity. What is a Hongkonger and what makes a person a Hongkonger? How does one make sense of being a Hongkonger and Chinese? There seems to be little hope of understanding how to untie this troublesome cultural knot if those questions are simplified into a heroic battle of democracy advocates assisting the free West against authoritarian China. ${ }^{344}$ What most legal scholars neglect are the economic facets of the Basic Law, which merit proper examination in general and in the politically unique Hong Kong context in particular. ${ }^{345}$ It is demonstrated that both Hong Kong and mainland China have benefited from each other enormously from their very special relationship in just about every way possible. ${ }^{346}$ Deng Xiao Ping reflects China's socialist attitude toward Hong Kong's development once again as the following:

"One Country, Two Systems" must be discussed on two levels. On one level is the fact that within a socialist country we will be permitting a specially privileged area to be capitalist not just for a short period of time, but for decades or a full century. On another level, we must affirm that the principal system throughout the country is socialist... That we uphold the socialist system and the "four cardinal principles" was determined long ago, and is inscribed in our Constitution. The policies we formulate, including our policies toward Hong Kong, Macao and Taiwan, are also determined on the basis of upholding the four cardinal principles. Without the Chinese Communist Party, and without China's socialism, who could formulate this type of policy? ${ }^{347}$

Focusing on China's Hong Kong policies offers important lessons on the rise and fall of Hong Kong's constitutional order. The formula of OCTS has a hidden time-code that is to be decrypted with careful constitutional analysis. From colonialism to OCTS, there is a range of constitutional choices by which good governance may be achieved for the polity. Constitutionalizing OCTS and thinking beyond 2047 allows us, especially the people of Hong Kong, to better understand and respond to the changing circumstances for any future developments. Nonetheless, all kinds of Article 5 interpretations have ultimately led to the most fundamental question: What is the constitutional fate of Hong Kong from now until 2047 and beyond? Is it a constitutional underdeterminacy that is "rule-guided?" Or is it simply a constitutional indeterminacy under which a decision is unbound if and only if the law does not place any limit on the range of possible results? ${ }^{348}$ One thing is sure: A constitutional interpretation of "unchanged for 50 years" that allows for fundamental changes of OCTS will certainly cause great legal discontinuity, which then breeds instability.

Tensions between the two systems of mainland China and Hong Kong tend to be understood as inherent conflicts between the common law system and the socialist/civil law system in a larger

\footnotetext{
${ }^{343}$ Kemal Bokhary, The Rule of Law in Hong Kong Fifteen Years after the Handover, 51 Colum. J. TrAnSNAT'L L. 287, 288 (2013).

${ }^{344}$ David C. Donald, Hong Kong's Roles in Supporting the Economic Development of China, 6 CITY U. H.K. L. REV. 1, 25 (2019)

${ }^{345}$ Miron Mushkata \& Roda Mushkat, The Economic Dimension of Hong Kong's Basic Law: An Analytical Overview, 7 N.Z. J. PUb. \& INT'L L. 273, 275 (2009).

${ }^{346}$ Donald, supra note 344 , at 23.

${ }^{347}$ Guigo Wang \& Priscillia M.F. Leung, One Country, Two Systems: Theory into Practice, 7 PAC. RiM L. \& POL’y J. 279,285 (1998).

${ }^{348}$ According to Lawrence B. Solum, the law is indeterminate with respect to a given case if and only if the set of results in the case that can be squared with the legal materials is a nonidentical subset of the set of all imaginable results. See Lawrence B. Solum, On the Indeterminacy Crisis: Critiquing Critical Dogma, 54 U. CHI. L. Rev. 462, 473 (1987).
} 
international setting. ${ }^{349}$ For the foreseeable years, mainland China will never have radical changes of its ongoing socialist legal system. Meanwhile, Hong Kong, as an established capitalist system, has been struggling for its survival in recent years. Are the two distinct systems doomed to conflict? Will OCTS succeed? Is China free to depart from its basic policy on the segregation of the systems in 2047? Even if mainland China or Hong Kong fails on one front, at some point, will there be any case for OCTS in its general sense? A simplistic answer to all those questions is that time will tell. But that simple answer is an escape or circumvention of the constitutional destiny of Hong Kong. The constitutional experiment of OCTS ultimately determines the destiny of more than seven million inhabitants in Hong Kong. ${ }^{350}$ With all of the 2047 questions pending, it is equally vital to understand that worries, doubts, and anxieties are normal to the life of a constitution, given that, in Justice Holmes's words, all life is an experiment. In that sense, the constitutional puzzles of "unchanged for 50 years" must be addressed within the framework of the temporality of the Basic Law in a fast-paced world.

First, if the distinctions between OCTS and other forms of constitutional principles, including "one country, one system" or "one country, better system," are observed and honored, then there are always good arguments for constitutional principles in each context. For OCTS, the concern that the two systems operate asymmetrically need not matter. ${ }^{351}$ Not denying the widely known facts of "one country, one system" in both unitary states and federal states, China's adoption of OCTS as a constitutional principle has formed one of its constitutional cores (Verfassungskern), This core is then inexorable and cannot be amended. ${ }^{352}$ Abolishing or repealing OCTS amounts to repudiation of one of the main constitutional cores of China's 1982 Constitution. As long as the 1982 Constitution is not destroyed or remade, OCTS continues to serve as China's unshakeable foundation relating to SARs.

Second, adherence to OCTS, regardless of its specific form, means the peaceful co-existence of two distinct systems within one sovereign nation state. Though comparison of the coexistence of parallel sovereign states might be appealing, recognition of the two systems in Hong Kong and the mainland remains central. Deviation from the "one country" principle itself constitutes a grave violation of OCTS. Here, the true comparison should be "one country" against "not one country." 353 The constitutional principle of OCTS that operates in the mainland under certain conditions will be equally operative in Hong Kong where the same conditions are present in a more acute form. Once the present and future conditions of the mainland and Hong Kong were considered simultaneously during the drafting process of the Basic Law, each side was bound by the purposes of OCTS. Furthermore, OCTS under the 1982 Chinese Constitution-which clearly expresses the purpose it was meant to serve for the mainland-will also apply to Hong Kong where the identical purpose can be found in the Basic Law.

Third, the temporality of the Basic Law, which includes the principle of temporal inertia, ${ }^{354}$ prevents arbitrary changes without strong justifications upon the fundamental changes of the circumstances. Required by constitutional stability and predictability, which allow people to foresee the legal consequences of their actions across a long history, OCTS should be constitutionally maintained during the course of normal or minor changes of circumstances, including during the imposition of martial law or emergencies. Arbitrary changes of the political or economic system in Hong Kong or any capricious re-arrangements between the mainland and Hong Kong is contrary to the higher law nature of OCTS. Fundamental changes of circumstances may lead to

\footnotetext{
${ }^{349}$ Johannes Chan, A Storm of Unprecedented Ferocity: The Shrinking Space of the Right to Political Participation, Peaceful Demonstration, and Judicial Independence in Hong Kong, 16 ICON 373, 374, 387 (2018); Chan, supra note 226 , at 452.

${ }^{350}$ Johannes Chan, supra note 349 , at 388.

${ }^{351}$ YIN, supra note 257, at 28.

${ }^{352}$ Yaniv Roznai, Unconstitutional Constitutional Amendments-The Migration And Success of a Constitutional Idea, 61

Aм. J. Comp. L. 657, 713-15 (2013); Albert, supra note 341, at 74-75.

${ }^{353}$ YIN, supra note 257, at 28.

${ }^{354}$ Liaquat A. Khan, Temporality of Law, 40 McGeorge L. Rev. 55, 80, 106 (2009).
} 
the dismemberment of the Basic Law or the removal of the "separation wall" between the two systems, but these circumstances must be narrowly construed to the utmost extent such that the constitutional foundations of OCTS no longer exist.

Last but not least, because there are no established precedents of OCTS, every step is a first step, sometimes forward and sometimes backward. ${ }^{355}$ Thus, the concrete forms and methods of the constitutional principles may take various shapes from time " 1 " to time " 2 ." Based on the principle that every state has an inalienable right to choose its political, economic, social, and cultural systems, ${ }^{356}$ it is generally not prohibited for China to give concrete legal exemplifications as to how the 1982 Constitution and the Basic Law shall be interpreted. However, China's constitutional interpretation of the Basic Law is confined by the distinctions between constitutional change and constitutional dismemberment. The constitutional content of OCTS needs to be filled with the same spirit and purpose of the Basic Law as that of when it was drafted. One may argue for constitutional amendments of the Basic Law that might put OCTS to an end. But that argument is flawed. Even the NPC as a sovereign actor has the power to do so under Article 159 (1) of the Basic Law. No amendments shall contravene China's established basic policies regarding Hong Kong under Article 159 (4). Besides, under the theory of dismemberment, the alteration process aiming at constitutional changes would have to abide by the rule of mutuality, which imposes, as a default ceiling, the requirement that the dismemberment procedure mirror the procedure used to ratify the constitution. ${ }^{357}$

Is the question of 2047 too far away for us to make firm predictions at this time? ${ }^{358}$ Under the Confucian tradition, the Mandate of Heaven (T'ien-ming) shall be known to the Chinese within 50 years. ${ }^{359}$ Because we have been endowed with a weak Messianic power, a power to which the past has a claim, ${ }^{360}$ the great constitutional experiment so far has provided us with chances to grasp the constitutional fate of Hong Kong. For the tale of the two systems in China, OCTS embodies "vector forces both centripetal and centrifugal that ensure a measure of stability." 361 In order to maintain constitutional stability and endurance, for the long term well-being of more than seven million people in Hong Kong, the Basic Law must not be interpreted as a "suicide pact," 362 and to secure the unamendability of OCTS in 2047 will be the best blessing for Hong Kong in every possible way.

\footnotetext{
${ }^{355}$ Ted Hagelin, Reflections on the Economic Future of Hong Kong, 30 VAND. J. TransNaT'L L. 701, 702 (1997).

${ }^{356}$ G.A. Res. 2625, Annex, Declaration on Principles of International Law Concerning Friendly Relations and Co-Operation Among States in Accordance with the Charter of the United Nations (Oct. 24, 1970).

${ }^{357}$ Albert, supra note 341 , at 76 .

${ }^{358}$ GiTTINGS, supra note 8 , at 321 .

${ }^{359}$ CHAN, supra note 1.

${ }^{360}$ Benjamin, supra note 2.

${ }^{361}$ Laurence H. Tribe, The Invisible Constitution 207 (2008).

${ }^{362}$ Terminiello v. Chicago, 337 U.S. 1, 37 (1949) (Jackson, J., dissenting).
} 